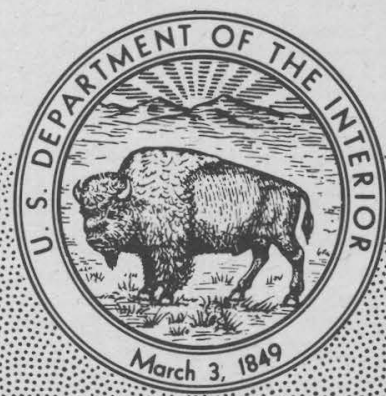

The Alaskan Mineral Resource Assessment Program: Background Information to Accompany Folio of Geologic and Mineral Resource Maps of the Ambler River Quadrangle, Alaska

Prepared in cooperation with the State of Alaska Department of Natural Resources, Division of Geological and Geophysical Surveys 

THE ALASKAN MINERAL RESOURCE ASSESSMENT PROGRAM 


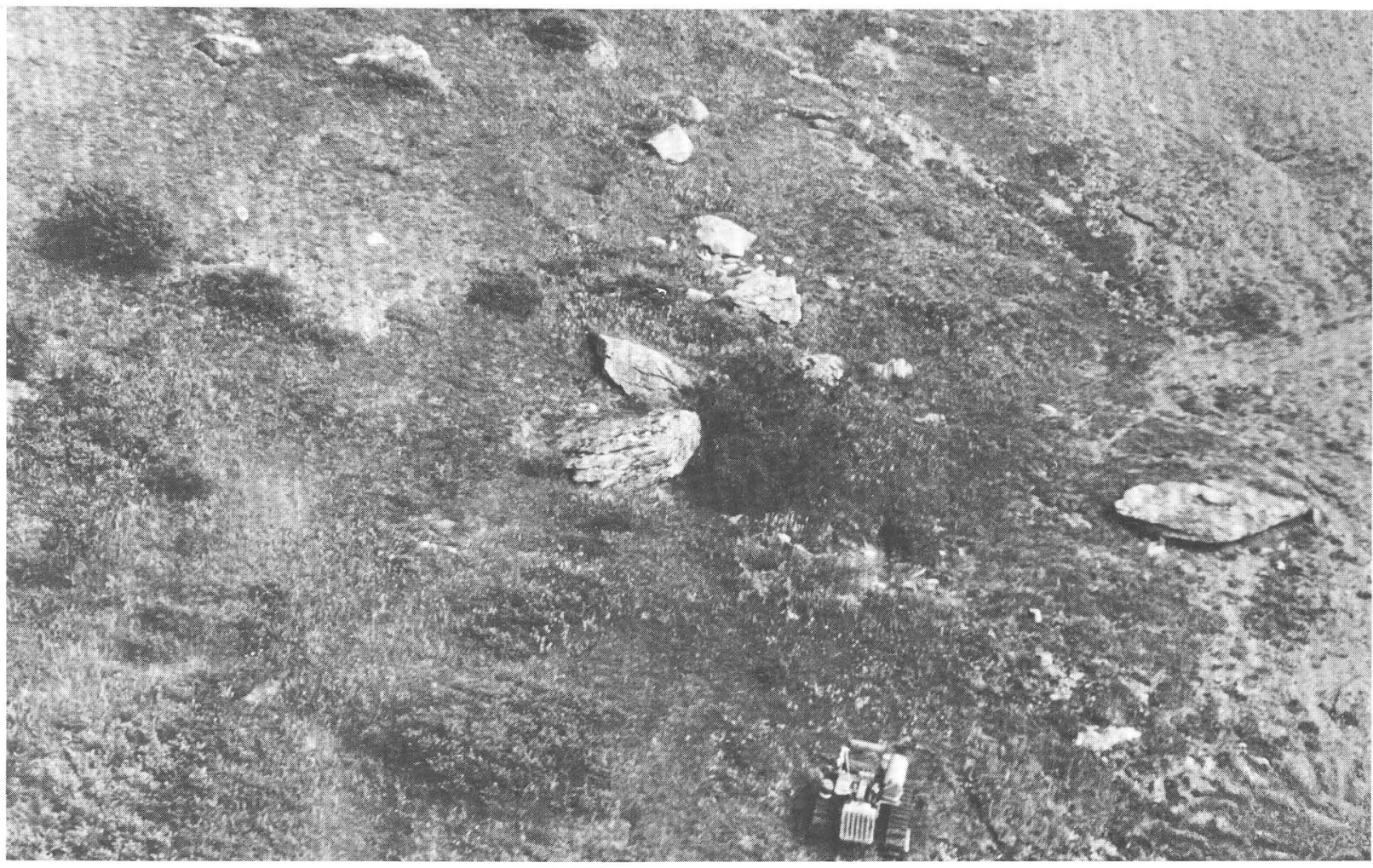

Large boulders of nephrite (jade) which have weathered from serpentinite at the jade prospect on south side of the Jade Mountains. (Photo by I. L. Tailleur, 1972)

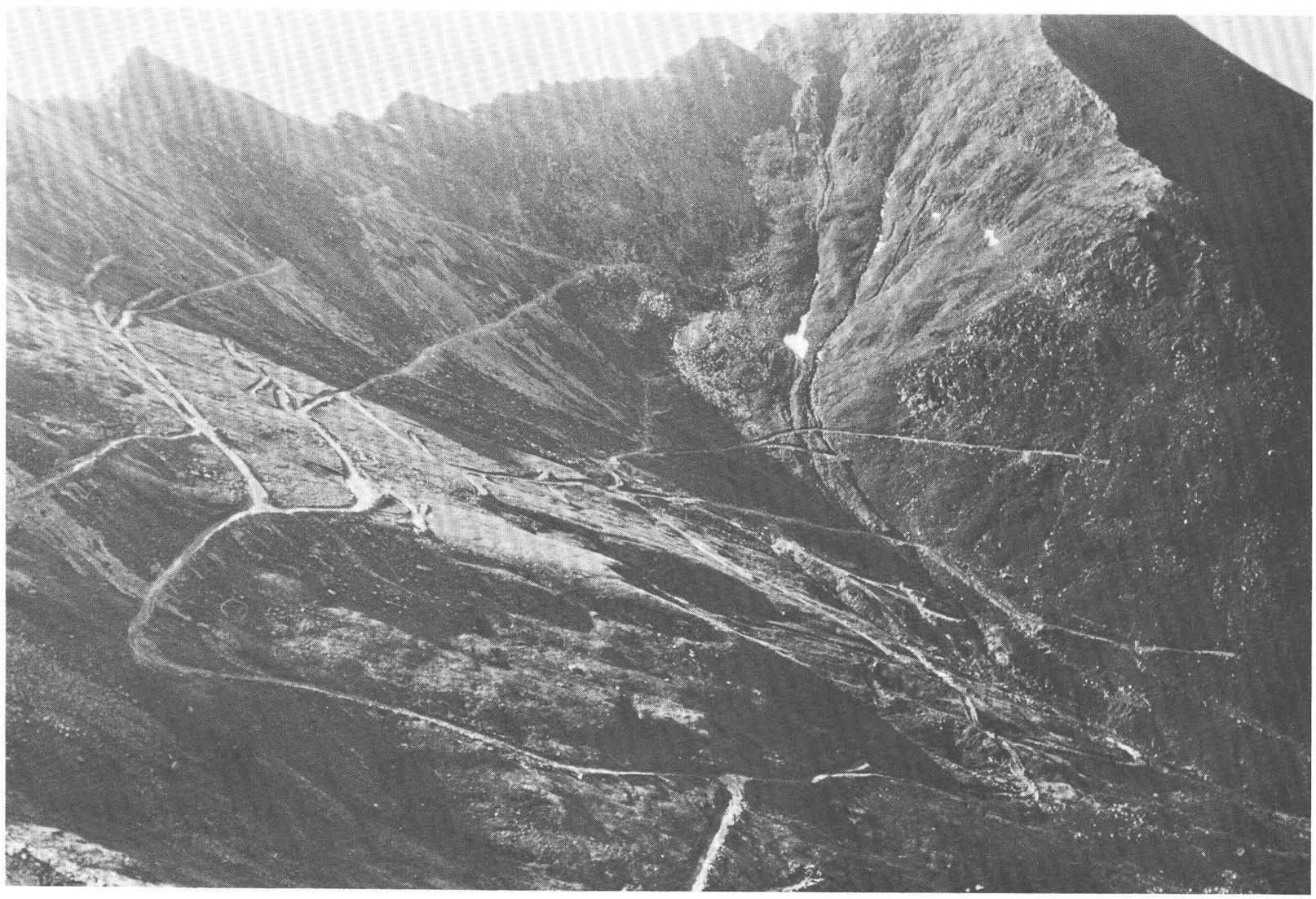

Exploratory development at the Arctic copper-zinc-lead-silver deposit on the ridge divide between the Kogoluktuk and Shungnak Rivers. (Photo by I. L. Tailleur, 1972) 
The Alaskan Mineral Resource Assessment

Program: Background Information to

Accompany Folio of Geologic and Mineral

Resource Maps of the Ambler River

Quadrangle, Alaska

By C. F. Mayfield, I. L. Tailleur, N. R. D. Albert, Inyo Ellersieck, Donald Grybeck, and S. W. Hackett

GEOLOGICAL SURVEY CIRCULAR 793

Prepared in cooperation with the State of Alaska

Department of Natural Resources, Division of

Geological and Geophysical Surveys 
United States Department of the Interior JAMES G. WATT, Secretary

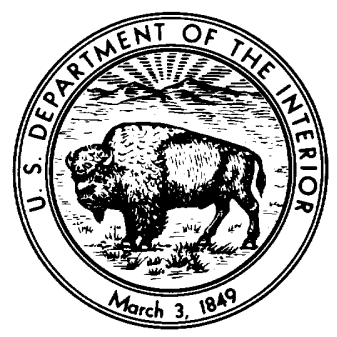

Geological Survey

Dallas L. Peck, Director

Library of Congress catalog-card No. 83-600555 


\section{CONTENTS}

Page

Abstract

Introduction

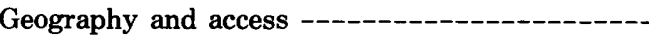

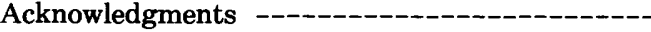

Summary of mineral exploration and production --..---

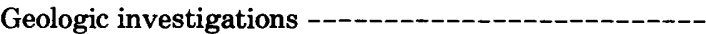

Previous geologic and mineral resource investigations ------_-_-_-_-_-

Present study --_-_-_-_-_-_-_-_-_-_-_-

Geology of the Ambler River quadrangle --

Geologic terranes --_-

Metamorphism

Very low-grade metamorphic rocks -- - - - - -

Low-grade metamorphic rocks

Low- to medium-grade contact metamorphic rocks -

History of metamorphism
1

1

1

1

2

4

4

4

5

6

6

9

9

9

11

11

Geology of the Ambler River quadrangle-Continued

Potassium-argon ages --_-_-_-_-_-_-_-- 12

Uranium-lead ages --_-_-_-_-_-_--_------ 12

Lead-alpha ages --_-_-_-_-_-_-_-_-- 13

Fossil localities --_-_-_-_-_- 16

Component maps of the Ambler River quadrangle folio ---_---_-_- 16

Geology report OF 78-120-A -_- 16

Reconnaissance geochemistry reports OF 78-120-B through $\mathrm{H}$--

Mineral occurrences and resources report OF 78120-I ---

Interpretation of Landsat imagery report OF 78120-J

Page

Aeromagnetic map and interpretation (report OF 78-120-K) - -

Bibliography 2

\section{ILLUSTRATIONS}

FRONTISPIECE. Jade prospect and the Arctic "copper-zinc-lead-silver" deposit in the Ambler River quadrangle

FIGURE 1. Index map of Alaska showing location of the Ambler River quadrangle and northeastern part of the Shungnak quadrangle 2-6. Maps showing:

2. Geologic terrances of the Ambler River quadrangle and northeastern part of the Shungnak quadrangle -------------

3. Metamorphic boundaries in the Ambler River quadrangle and northeastern part of the Shungnak quadrangle -- 4. Location of rocks that have been dated by radiogenic methods in the Ambler River quadrangle and northeastern part of the Shungnak quadrangle -

5. Fossil localities in the Ambler River quadrangle and northeastern part of the Shungnak quadrangle

6. Aeromagnetic terranes of the Ambler River quadrangle and northeastern part of the Shungnak quadrangle 


\section{TABLES}

TABLE 1. Component maps of the Ambler River quadrangle mineral resource assessment ----------------- 2

2. Potassium-argon ages from the Ambler River quadrangle -

3. Uranium-lead ages from the Ambler River quadrangle -

4. Lead-alpha ages from the Ambler River quadrangle --_-_-

5. Fossils collected in the Ambler River quadrangle -

6. Estimate of number, grade, and tonnage of volcanogenic deposits --- 


\title{
The Alaskan Mineral Resource Assessment Program: Background Information to Accompany Folio of Geologic and Mineral Resource Maps of the Ambler River Quadrangle, Alaska
}

\author{
By C. F. Mayfield, I. L. Tailleur, N. R. D. Albert, Inyo Ellersieck, Donald Grybeck, and S. W. Hackett'
}

ABSTRACT

The Ambler River quadrangle, consisting of $14,290 \mathrm{~km}^{2}\left(5,520 \mathrm{mi}^{2}\right)$ in northwest Alaska, was investigated by an interdisciplinary research team for the purpose of assessing the mineral resource potential of the quadrangle. This report provides background information for a folio of maps on the geology, reconnaissance geochemistry, aeromagnetics, Landsat imagery, and mineral resource evaluation of the quadrangle. A summary of the geologic history, radiometric dates, and fossil localities and a comprehensive bibliography are also included. The quadrangle contains jade reserves, now being mined, and potentially significant resources of copper, zinc, lead, and silver.

\section{INTRODUCTION}

PURPOSE AND SCOPE

This circular and a separately available folio of maps constitute a compilation and assessment of the mineral resources of the Ambler River quadrangle, Brooks Range, Alaska, prepared under the auspices of the Alaskan Mineral Resource Assessment Program (AMRAP). The purpose of AMRAP is to provide basic information which will help Federal, State, and local agencies and industry formulate mineral resource policies and provide a basis for making local land-use planning decisions. AMRAP also intends to update existing mineral resource compilations, to help stimulate private resource development, and to increase understanding of the geology of Alaska.

${ }^{1}$ Alaska Division of Geological and Geophysical Surveys, Fairbanks, Alaska 99701.
The 11 maps in the folio of the Ambler River quadrangle mineral resource assessment are listed in table 1. The folio is an integration of the geology, geochemistry, geophysics, telegeology, and mineral occurrences into a series of reports that summarize the currently known mineral resource potential of the quadrangle. It represents the efforts of an interdisciplinary team of geoscientists, each contributing knowledge in his field of specialty to the resource assessment.

This circular is designed to not only draw attention to the folio of mineral assessment maps but also to provide background information relevant to understanding what is known about the complex geology of the quadrangle. New information that has become available since the publication of the maps in the folio is also presented. The circular includes a brief history of mineral exploration and production, a summary of the geology, and description of the regional metamorphism, and a compilation of rock ages based on radiometric dates and fossil localities. This is followed by a short description of each component map in the folio. In addition, the circular contains a comprehensive geologic bibliography of the Ambler River quadrangle.

\section{GEOGRAPHY AND ACCESS}

The Ambler River quadrangle covers approximately $14,290 \mathrm{~km}^{2}\left(5,520 \mathrm{mi}^{2}\right)$ in northwestern Alaska (fig. 1) between $67^{\circ}$ and $68^{\circ} \mathrm{N}$. latitude and $156^{\circ}$ and $159^{\circ} \mathrm{W}$. longitude. An addition of part of the Shungnak quadrangle to the southeast corner of the Ambler River quadrangle has been included in the folio resource assessment maps to show the 
TABLE 1.-Component maps of the Ambler River quadrangle mineral resource assessment

U.S. Geological Survey Open-File (OF) Reports

Subject

OF 78-120-A (Mayfield and Tailleur, 1978)

OF 78-120-B (Ellersieck, 1978f)

78-120-C (Ellersieck, 1978a)

OF 78-120-D (Ellersieck, 1978e)

OF 78-120-E (Ellersieck, 1978d)

OF 78-120-G (Ellersieck, 1978b)

OF 78-120-H (Ellersieck, 1978c)

OF 78-120-I (Mayfield and Grybeck, 1978)

OF 78-120-J (Albert, 1978)

OF 78-120-K (Hackett, 1980)

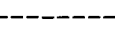

Geology.

Stream-sediment geochemical sample locations.

Analytical results for streamsediment samples.

Lead and zinc geochemical anomalies.

\section{Copper and} molybdenum geochemical anomalies.

Tin and beryllium geochemical anomalies.

Barium, silver, and arsenic geochemical anomalies.

Chromium, nickel, and cobalt geochemical anomalies.

Mineral occurrences and resources.

Interpretation of satellite imagery.

Aeromagnetic map and interpretation. entire geology of the Cosmos Hills. The Baird and Schwatka Mountains of the southwest Brooks Range trend in a west-northwesterly direction through the central part of the area. Streams in the south half of the quadrangle flow into the Kobuk River, and in the north half, they flow into the Noatak River. Elevations range from $30 \mathrm{~m}$ (100 ft) along the lower Kobuk River in the southwest to just over $1970 \mathrm{~m}(6,000 \mathrm{ft})$ in the Schwatka Mountains in the east-central part of the quadrangle. Most of the mountains rise to $1,000-1,300 \mathrm{~m}$ $(3,000-4,000 \mathrm{ft})$ and intervening valleys from about 160 to $650 \mathrm{~m}(500$ to $2,000 \mathrm{ft})$. The area has undergone multiple stages of glaciation in the Pleistocene which formed the broad U-shaped valleys that contain most of the larger streams in the mountains (Fernald, 1964). Remnants of these glaciers are visible as small stagnant ice fields in a few of the north-facing cirques in the east-central part of the quadrangle.

The Ambler River quadrangle is situated in the back country of Alaska. There are no roads leading into the area, and the most feasible access is by airplane. There are three improved dirt airstrips. One is located at the village of Ambler on the Kobuk River, and the other two are in the Cosmos Hills at the mining camp of Bornite on Ruby Creek and near Dahl Creek. As a result, access to most other areas is by helicopter or by light plane which must land on gravel bars or small lakes. The distance to the nearest supply centers are Kotzebue, $230 \mathrm{~km}$; Bettles, $260 \mathrm{~km}$; and Fairbanks, $530 \mathrm{~km}$. Access can also be gained to the quadrangle by small boat on the Kobuk or Noatak Rivers. Larger items can be brought into the area by barge from Kotzebue during the summer months if the Kobuk River is high enough. There is a dirt road between the village of Kobuk on the Kobuk River and the mining camp of Bornite in the Cosmos Hills.

The only permanent town in the quadrangle is Ambler, with a population about 200 , located at the confluence of the Kobuk and Ambler Rivers. The mining camps of Bornite, in the Cosmos Hills, and Arctic Camp, on a tributary of the Ambler River, have a seasonal fluctuation in population from caretaker status in the winter up to several dozen people in the summer. Except for irregularly occupied cabins strung out along the Kobuk River and transitory mining exploration camps in the southeastern part of the quadrangle, the remainder of the area is infrequently occupied or visited.

Acknowledgments.-The Ambler River AMRAP project is a combined effort between geoscientists from the Alaska Division of Geological and Geophysical Surveys (ADGGS) and the U.S. Geological Survey. Appreciation is given to G. H. Pessel, R. E. Garland, G. R. Eakins, and M. A. Wiltse of 


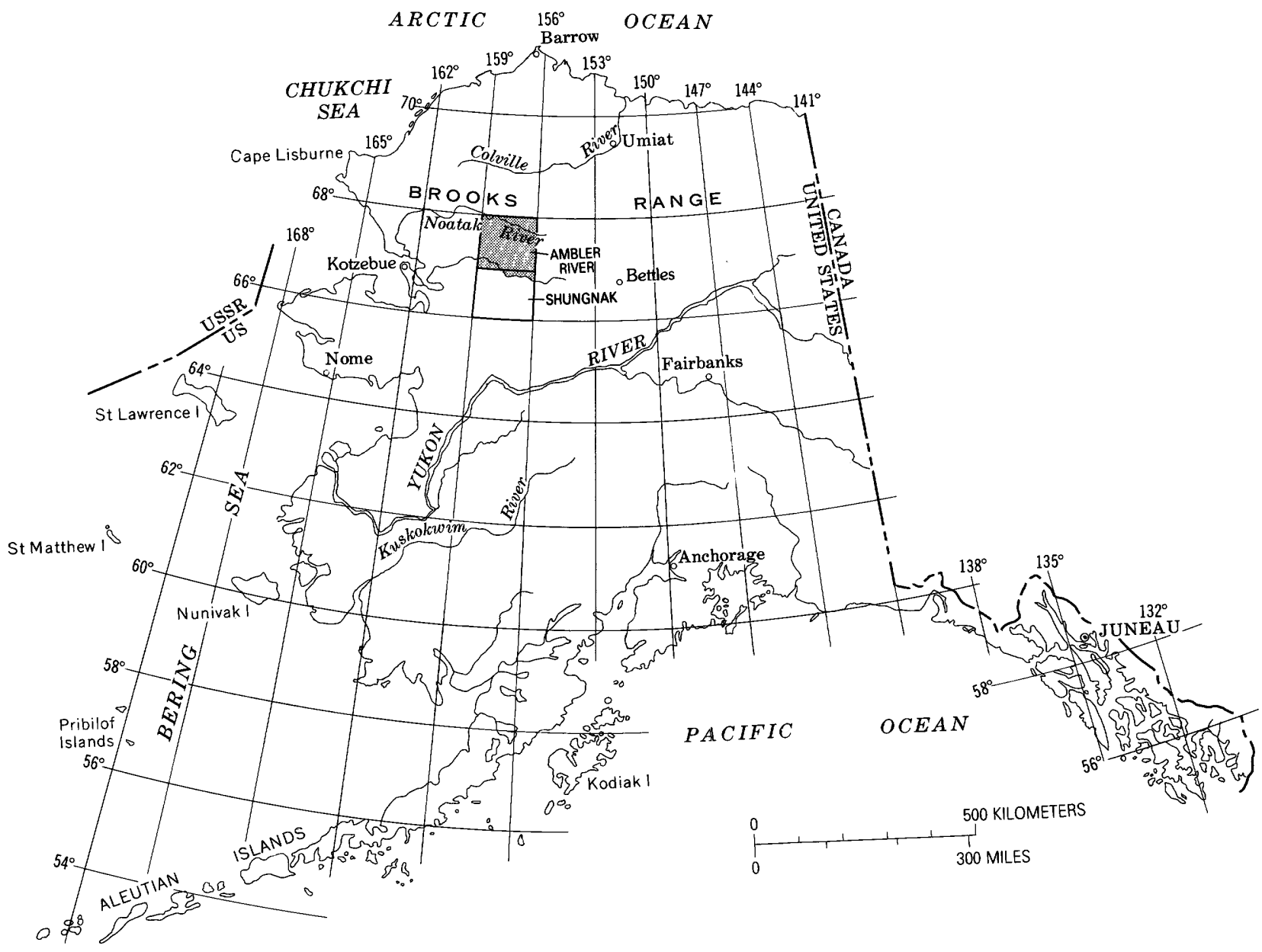

Figure 1.-Index map of Alaska showing the location of the Ambler River quadrangle and the northeastern part of the Shungnak quadrangle. Area of report is shaded.

the ADGGS and W. P. Brosge of the U.S. Geological Survey who helped conduct the early phases of investigation but did not take a direct role in the compilation of this circular or the folio of mineral assessment maps. These geologists have graciously made available field notes, rock samples, thin sections, and mineral occurrence localities as well as provided us with helpful concepts relating to the general geology of the quadrangle. Other scientists, who visited the area and helped with geologic mapping, petrography, and age dating, are W. B. Hamilton of the U.S. Geological Survey, W. G. Gilbert of the ADGGS, and R. B. Forbes, J. R. Carden, and D. L. Turner of the University of Alaska Geophysical Institute.

The work was greatly facilitated by the help of local citizens or other workers engaged in various aspects of exploring the country. The cooperation of many people engaged in minerals exploration, particularly H. A. Sichermann, R. H. W. Chadwick, N. L. Lutz, R. C. Babcock Jr., and Richard Walters (all formerly with Bear Creek Mining Company) is appreciated. They shared their ideas and contributed logistical support when needed. Tommy Douglas, from Ambler, and John Moyer, from Kobuk, provided helpful information on mineral occurrences and past mining history. Data on some mineral prospects come from the following exploration companies: Anaconda Mining Company, Bear Creek Mining Company, Noranda Exploration, and WGM Inc. Also Buck Maxson of Maxson's Aviation was of great help in giving competent and reliable supply by bush plane to a remote field camp on the Noatak River. Office and laboratory personnel giving much needed assistance include T. C. Trible of the State of Alaska Mineral Analysis and Research Laboratory and R. M. O'Leary, S. K. McDanal, and C. M. 
McDougal of the U.S. Geological Survey for providing chemical analyses and computer compilations of the geochemical sampling data.

\section{SUMMARY OF MINERAL EXPLORATION AND PRODUCTION}

Gold has been the principal commodity produced from the quadrangle. The first discoveries are believed to have been made in the Cosmos Hills in 1898 or 1899 which led to a small gold rush about 1900. Most gold was produced between 1900 and 1940 with peak production from 1910 to 1920 from placers located on Dahl Creek, California Creek, and the Shungnak River. Placer operations continued on a smaller scale to the early 1960 's; in recent years placer claims have been largely inactive. The total amount of gold produced is estimated to be between 466 and $1244 \mathrm{~kg}$ (15,000 and 40,000 oz) almost entirely mined from placers in the Cosmos Hills.

During the gold rush, copper prospects were discovered at Pardners Hill and Ruby Creek in the Cosmos Hills, where a small amount of trenching and tunneling was done. In 1948, interest in the properties was revived when airborne surveys showed a radiometric anomaly associated with the old copper prospect at Ruby Creek. Rhinehart Berg prospected the anomaly by bulldozing, trenching, and a small amount of drilling which uncovered enough mineralized ground to interest Bear Creek Mining Company into conducting a systematic drilling program in 1958 and 1959. This program resulted in the discovery of significant quantities of high-grade copper ore in carbonate breccia. A more complete history of the exploration of the Ruby Creek deposit is reported by Fritts (1970). The discovery at Ruby Creek encouraged the Bear Creek Mining Company to conduct geochemical exploration in the mountains north of the Cosmos Hills. This exploration, in the mid 1960's, resulted in the discovery of several volcanogenic deposits of which the Arctic deposit has the largest known reserves. In recent years, exploration by several mining companies has resulted in the discoveries of several additional volcanogenic deposits. Mining and development of these deposits beyond the initial assessment stage have not yet begun.

Occurrences of asbestos minerals have been known from several localities on the south edge of the Brooks Range since the gold rush. The only attempt at mining any of these prospects was at the Ing-Ihk mine in the Cosmos Hills in 1944-1945 (Coats, 1944; Heide and others, 1949). The operation was discontinued soon after a 47-ton test shipment of high-grade ore was made.

Jade from deposits in the Jade Mountains and Cosmos Hills had been collected and traded by the Eskimos long before white men ventured into the Arctic. These are the largest known deposits in Alaska. Since World War II, jade mining has supported one- and two-man summer operations in the Jade Mountains and Cosmos Hills. Although production estimates have never been reported, reserves at these locations are expected to keep small operations in business for many years. The deposits presently supply most of the commercial jade mined in Alaska.

\section{GEOLOGIC INVESTIGATIONS}

\section{PREVIOUS GEOLOGIC AND MINERAL RESOURCE INVESTIGATIONS}

The first exploration of the central Kobuk Valley was made in 1884 and 1885 by two separate parties under different auspices. The first was led by J. C. Cantwell of the U.S. Revenue Marine Service (Cantwell, 1889; McLenegan, 1889), and the second was led by Lt. G. M. Stoney of the U.S. Navy (Stoney, 1900). Stoney's party wintered over at a camp on the Kobuk River south of the Cosmos Hills from which exploration was made into the nearby mountains and Noatak valley. The first recorded exploration into the Noatak valley was in 1885 by S. B. McLenegan of the U.S. Revenue Marine Service (McLenegan, 1887). When gold was discovered in the Cosmos Hills in 1898 or 1899, many prospectors ventured into this unknown territory. A prospector's account of the early conditions in 1898 is given by Grinnell (1901). The first expedition into the area by the U.S. Geological Survey was led by W. C. Mendenhall, who descended the Kobuk River and mapped the geology along the river at a scale of approximately 1:1,250,000 (Mendelhall, 1902). The first mineral investigation was conducted by $\mathrm{P}$. S. Smith during traverses of the Kobuk and Noatak valleys in 1910 and 1911 (Smith, 1913; Smith and Eakin, 1911). In 1931, Irving Reed wrote a brief description of the placer mining operations in the 
Cosmos Hills (Reed, 1931). Many other reports of the Alaska mining industry cover the estimated yearly gold production from the period 1904 to 1942. The most notable of these reports, by A. H. Brooks and by P. S. Smith, have been published as a series of U.S. Geological Survey Bulletins listed in the bibliography at the end of this report. A systematic compilation of mineral occurrences in the northwestern Brooks Range was made by Eskil Anderson during World War II (Anderson, $1945 ; 1947)$. At the end of the war, the asbestos deposits in the Cosmos Hills and Jade Mountains were evaluated by the U.S. Bureau of Mines (Heide and others, 1949) and the U.S. Geological Survey (Coats, 1944).

Post-World War II studies by the U.S. Geological Survey included geologic reconnaissance of the Ambler River and adjacent quadrangles by I. L. Tailleur in 1955, 1958, and 1965. He compiled a large-scale geologic map of the Cosmos Hills and smaller scale maps of the mountains to the north; these maps are unpublished but have provided a basic framework for later geologic maps and studies in the quadrangle. In 1965 and 1966, the southern part of the quadrangle was investigated by Tailleur, W. W. Patton, Jr., and T. P. Miller, and they compiled a 1:250,000 scale geology map of the region (Patton and others, 1968). Additional reconnaissance mapping of the north and central parts of the quadrangle was carried out by Tailleur, W. P. Brosgé, and H. N. Reiser during 1966 (Brosgé and others, 1967). The observed relations between Paleozoic clastic and carbonate units contributed significantly to an understanding of the stratigraphy and restored depositional settings of the Endicott and Baird Groups (Tailleur and others, 1967). Detailed aspects of the geology of the copper deposit on Ruby Creek are given in a $\mathrm{Ph}$.D. dissertation and subsequent publications by D. D. Runnells $(1963,1964,1965,1966$, and 1969). Other prospect examinations were made by various government agencies and mining companies during the 1950's, 1960's, and 1970's. Because most of these reports are unpublished, they are not readily available. The reports that have been brought to our attention are included in the bibliography of this report.

In 1968 and 1969, C. E. Fritts of the Alaska Division of Mines and Geology completed a project of detailed geologic mapping and geochemical sampling in the Cosmos Hills (Fritts, 1969a, b; 1970). In 1971, Fritts began a similar project in the southern part of the Schwatka Mountains which continued until his untimely death in a canoeing accident on the Kogoluktuk River in 1972. G. H. Pessel, R. E. Garland, and G. R. Eakins resumed the field operations in the same year and requested Tailleur's assistance. This is the year the current project began, and it continues with the publication of this circular as a cooperative effort between the Alaska Division of Geological and Geophysical Surveys and U.S. Geological Survey.

\section{PRESENT STUDY}

Most of the field and laboratory work closely related to this study was begun in 1972 by Pessel, Garland, and Eakins of the ADGGS and Tailleur of the U.S. Geological Survey. These workers released stream-sediment geochemical analyses (Garland and Pessel, 1975) and a geologic map of the southeastern part of the quadrangle at 1:63,360 scale (Pessel and others, 1973). In 1973 and 1974, Pessel and Tailleur were joined by Brosgé of the U.S. Geological Survey, and the project was expanded in the mountains of the south-central and southwestern part of the quadrangle. Stream-sediment geochemical analyses from this part of the area were released by Garland and others (1975) and Pessel (1976). Detailed mapping and study of selected volcanogenic deposits were carried out by M. A. Wiltse (1975). Gilbert and others (1977) completed a geologic and geophysical cross-section in the Ruby Ridge area of the metamorphic terrane which contains the volcanogenic deposits. A preliminary geologic map at 1:250,000 scale was compiled by Pessel and Brosgé (1977) from fieldwork of the years 1955-1966 and 1972-1974). Geologic mapping and geochemical sampling in the north half of the quadrangle were concluded in 1976 by Tailleur, Mayfield, and Ellersieck. An aeromagnetic survey was flown in the western and eastern parts of the quadrangle in 1974 and 1975 under contract to the ADGGS. The resulting aeromagnetic contour maps were released by S. W. Hackett (1977). Landsat imagery was analyzed in 1978 by N. R. D. Albert. Although many of the above-mentioned geologists did not take an active role in the mineral resource assessment of the Ambler River quadrangle, their published reports as well as rock samples, field notes, and informal discussions constitute a valuable contribution to this report and to the mineral assessment maps. 


\section{GEOLOGY OF THE \\ AMBLER RIVER QUADRANGLE}

\section{GEOLOGIC TERRANES}

Rocks in the Ambler River quadrangle are here broadly divided into five terranes on the basis of age and lithologic association. These geologic subdivisions are: the Kobuk River terrane, the Jade Mountains-Angayucham Mountains terrane, the schist belt terrane, the Schwatka Mountains terrane, and the Endicott Mountains terrane (fig. 2).

The Kobuk River terrane is located along the south edge of the quadrangle where it consists of the rocks of the Kobuk valley and southern foothills of the Brooks Range. Most of the area is covered by forest or tundra growing on a veneer of unconsolidated alluvial and glacial deposits. Bedrock, exposed discontinuously in stream cuts or hilltops, consists of folded and faulted Early Cretaceous sedimentary rocks which are the youngest rocks in the quadrangle. These rocks mostly consist of micaceous quartz conglomerate and lesser interbedded sandstone and mudstone that have a few thin coal seams visible in stream cuts along the lower Ambler River. Induration of the rocks appears to increase toward the north and is greatest in the sedimentary strata flanking the Cosmos Hills where, in some places, conglomerate clasts appear to be tectonically stretched. Bedrock in this terrane generally dips south and unconformably onlaps rocks of the Jade MountainsAngayucham Mountains terrane to the north.

The Jade Mountains-Angayucham Mountains terrane, located along the south flank of the Brooks Range, consists of a relatively narrow belt of mafic and ultramafic rocks with minor chert, fine-grained clastic rocks, and reef carbonate rocks. Mafic rocks are mostly diabase and basalt with local pillow structures and may be of several different ages. In some places, where they were most highly recrystallized by regional metamorphism, they have been transformed to fine-grained chlorite-albite schist. In the Angayucham Mountains the rocks are not strongly metamorphosed, and bedded chert, correlative with Triassic chert east of the quadrangle (Plafker and others, 1978), is locally found associated with the basalts. Ultramafic rocks consist of discontinuous serpentinites in the Cosmos Hills and Angayucham Mountains and serpentinized dunite or peridotite in the Jade Mountains and near the Hunt River. In the Jade Mountains, peridotite or dunite rests upon diabase or basalt with a probable fault contact. In many places, serpentinite was probably squeezed into shear zones(?) in either mafic or carbonate and shale sequences. Paleozoic limestone and dolomite and intercalated phyllite occur structurally below most mafic-ultramafic rocks. However, in the breached antiform that is exposed in the Cosmos Hills, middle Paleozoic carbonate rocks may have been locally intruded by mafic igneous rocks or may have been deposited contemporaneously with mafic volcanic rocks (Fritts, 1970). Carbonate rocks are more than $200 \mathrm{~m}$ thick in some places in the Cosmos Hills and Jade Mountains and completely absent or thin and discontinuous in other places. Except for north-dipping beds along the north side of the Cosmos Hills antiform, rocks of this terrane dip south away from the Brooks Range. In most exposures, ultramafic rocks overlie mafic rocks which in turn overlie carbonate rocks and phyllite. This west-trending belt of mafic and ultramafic rocks flanking the mountains may represent a late Mesozoic plate boundary between what is now the Yukon-Koyukuk Province to the south and the Brooks Range to the north (Tailleur, 1973; Patton and others, 1978; Roeder and Mull, 1978).

The schist belt terrane is a thick accumulation of metamorphosed sedimentary rocks constituting the south half of the Baird and Schwatka Mountains. Most rocks are gray phyllite or quartz-mica schist thought to have been a thick pile of predominantly pelitic clastic rocks prior to being metamorphosed. Greenstone and amphibolite, metamorphosed from mafic igneous rocks, are dispersed throughout the terrane but make up only a relatively small volume of it. Included within the east half of the terrane is the volcanogenic copper belt, which, in addition to the rocks described above, also contains felsic schist, carbonaceous schist, and marble. The volcanogenic stratabound copper-zinc-lead-silver deposits are generally associated with felsic schist. Metamorphic recrystallization is greatest in the north and central parts of the terrane and becomes progressively less intense at the south edge of the mountains where the rocks are predominantly phyllite. Folding is complex and commonly isoclinal and shows more than one period of deformation. The age of the schist belt rocks may be both Precambrian and Paleozoic. The age of metamorphism of these rocks is controversial; it may have occurred at certain stages in the Precambrian, Paleozoic, and Mesozoic (Gilbert and others, 1977; Turner and 


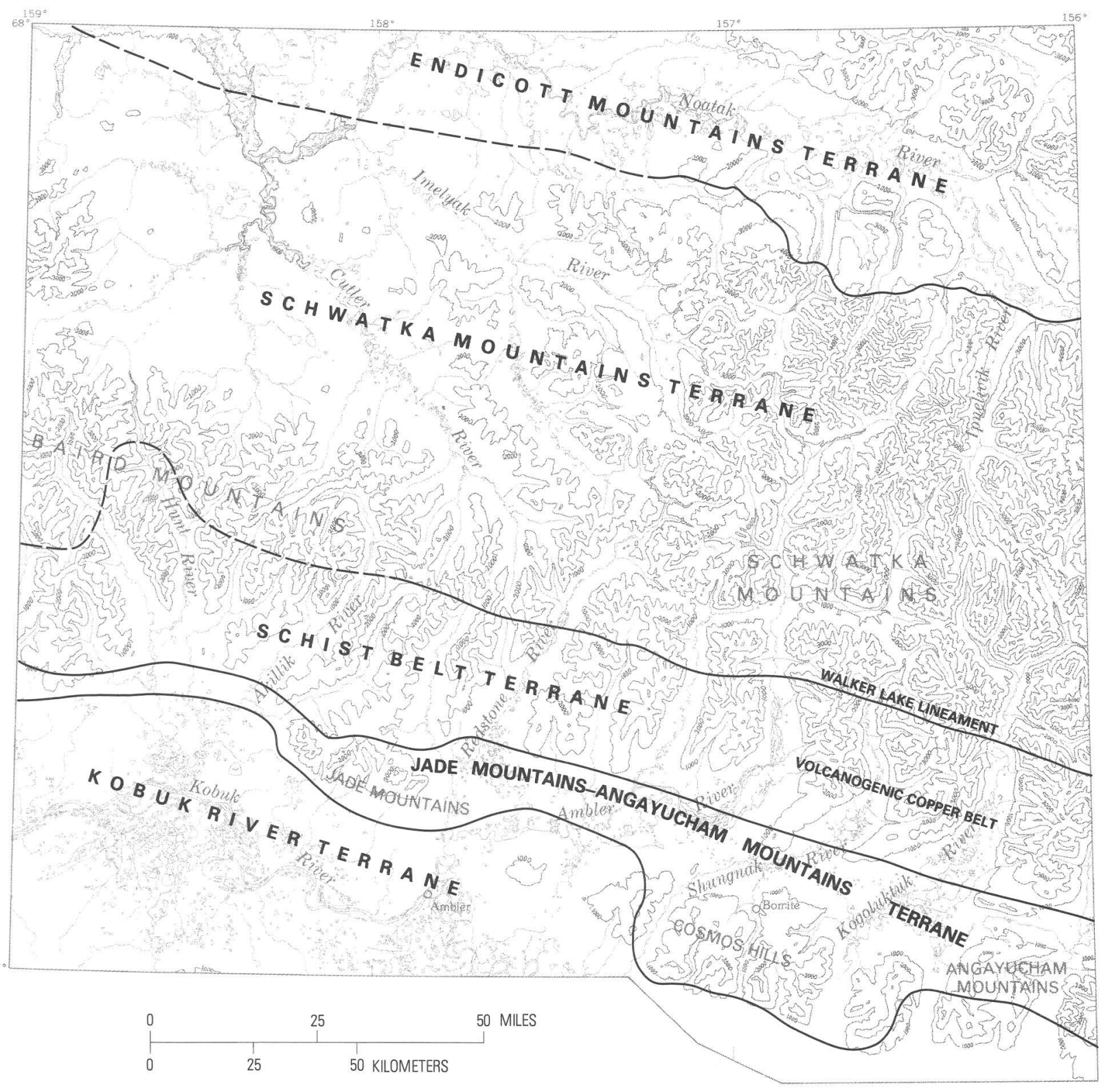

FIGURE 2.-Geologic terranes of the Ambler River quadrangle and the northeastern part of the Shungnak quadrangle.

others, 1978; Smith and others, 1978; Dillon and others, 1980).

The northern contact of the schist belt terrane is a sharp lithologic boundary in the east half of the quadrangle. Fritts (1970) originally called this contact the western extension of the Walker Lake fault that he first mapped in the Survey Pass quadrangle. Later semidetailed maps (Pessel and others, 1973; Pessel and Brosgé, 1977) show that it may instead be a major stratigraphic unconformity. The age of the rocks adjacent to the boundary is not known, and the contact is parallel to the strike of metasedimentary rocks in most areas. In the west half of the Ambler River quadrangle, the northern boundary of the schist belt is not so sharply defined, possibly because this lithologic break has been folded and faulted along the contact.

The north-central part of the Ambler River quadrangle is herein called the Schwatka Mountains terrane. This terrane consists of a variety of metasedimentary rocks of which the early and middle Paleozoic Skajit Limestone is most widely exposed. Calcareous schist, quartzite, dolomite, 
phyllite, and felsic volcanic(?) rocks also make up large parts of this terrane. Metamorphosed granitic plutons of probable middle Paleozoic age have intruded the rocks of the southern part. Recrystallization has obliterated the fossil record in most areas, but it is believed that the rocks are predominantly Paleozoic. The oldest known rocks in this terrane are Ordovician; this age is based on stratigraphic correlation with graptolite-bearing rocks located west of the quadrangle (U.S. Geological Survey, 1975b). The age of the youngest rocks, probably Permian, is based upon stratigraphic correlation with rocks located east of the quadrangle (Mull and Tailleur, 1977). The northeast edge of the terrane is overlain by progressively less metamorphosed clastic rocks of Late Devonian age.

The northern part of the Ambler River quadrangle, called the Endicott Mountains terrane (fig. 2), is composed of north-dipping sedimentary rocks that structurally overlie the Schwatka Mountains terrane. It is an allochthonous sequence mostly composed of Late Devonian shale, sandstone, and conglomerate that was deposited as a thick clastic wedge. The rocks were derived from a north-toeast source area (Donovan and Tailleur, 1975; Nilsen and others, 1980). These sedimentary rocks and the younger Paleozoic and Mesozoic rocks that stratigraphically overlie them in the Howard Pass quadrangle to the north are distinctly different from the partly coeval sequence of rocks in the Schwatka Mountains terrane. The best explanation for these regional structural and stratigraphic relations is that the Endicott Mountains terrane in the Ambler River quadrangle represents the south edge of the Brooks Range allochthon (Martin, 1970; Mayfield and others, 1978; Ellersieck and others, 1979) and is the lower part of a series of coeval allochthonous sequences that were thrust northward more than $150 \mathrm{~km}$ in the Early Cretaceous orogeny to create the bedrock that is exposed in the DeLong and Endicott Mountains of the north half of the Brooks Range (Mull and others, 1976). If this reconstruction is correct, then the Kanayut ConglomerateHunt Fork Shale clastic wedge was deposited south of the schist belt terrane and was derived in part from rocks eroded from the Schwatka Mountains terrane, possibly unmetamorphosed parts of the schist belt terrane, and other terranes currently in the subsurface north of the quadrangle.

This hypothesis requires a relatively simple structural history during the Brooks Range orogeny in which rocks to the south were successively thrust over (or underthrust by) rocks to the north (Tailleur and Snelson, 1969; Mull and others, 1976; Gealey, 1980). Another attraction of this scheme is that it requires the Endicott Mountains terrane and overlying allochtons to be deposited on a continental shelf south of the Schwatka Mountains and schist belt terranes which results in an orderly succession of the major facies patterns from the Devonian to the Jurassic. Some geologists have found this hypothesis unappealing because the Endicott Mountains terrane does not reappear at the south edge of the Brooks Range. For this hypothesis to be correct, it requires that the Endicott Mountains terrane was completely thrust over the Schwatka Mountains and schist belt terranes or that a southward extension of the sequence that contains the Kanayut Conglomerate and Hunt Fork Shale is buried beneath Cretaceous sedimentary rocks south of the Brooks Range.

Dutro and others (1976) favor an alternative explanation for the similar structural position of the Endicott Mountains terrane to the east in the Wiseman quadrangle. They suggest that this terrane was first thrust southward over coeval and older rocks and later was thrust northward to produce the characteristic northward overturned folds and northward directed thrust faults of the Endicott Mountains. This hypothesis requires the source area for the Kanayut-Hunt Fork clastic wedge to be in the subsurface of the North Slope, and it requires a more complex structural evolution for the Brooks Range where southward overthrusting, which is not strongly supported by structural evidence, was followed by northward overthrusting.

Dutro and others' (1976) hypothesis does not take into account the problems that arise in explaining the distinctive allochthons, each composed of Devonian or Mississippian to Cretaceous sedimentary rocks, which structurally overlie and are coeval with the sequence of rocks that contains the Endicott Mountains terrane north and west of the Ambler River quadrangle. If the Endicott Mountains terrane and the structurally higher allochthons were part of the same extensive depositional basin located north of the Schwatka Mountains terrane, as was implied by Dutro and others' (1976) hypothesis, then still left to be explained are (1) how this greater than $250 \mathrm{~km}$-wide Devonian to Jurassic depositional basin became stacked up on itself and (2) how the complex depo- 
sitional facies patterns were distributed in northern Alaska prior to the Brooks Range orogeny.

\section{METAMORPHISM}

Most rocks in the central part of the Ambler River quadrangle have undergone low-grade regional dynamothermal metamorphism (Winkler, 1979). The structural grain of both the foliation and strike of metasedimentary rocks trends westnorthwest following the higher topography of the mountain belt. Metamorphic recrystallization is highest in the central Baird and Schwatka Mountains where fine-grained clastic rocks have been transformed to quartz-mica schist. Flanking the mountains along the Kobuk and Noatak valleys, fine-grained clastic rocks are best described as slate or phyllite. In the southeastern corner of the quadrangle, the Cosmos Hills antiform is ringed by strongly indurated and partially recrystallized metasedimentary rocks, which become progressively more metamorphosed toward the center of the arch to phyllite and quartz-mica schist. Rocks exposed in the axis of the Cosmos Hills antiform resemble rocks in the schist belt both lithologically and in metamorphic grade.

Hundreds of rock samples taken during the course of the current and previous studies in the area have been examined petrographically. A plot of the mineral assemblages was used to construct a map that shows areas of different metamorphic grade (fig. 3). Each grade has common mineral assemblages that reflect differences in temperature and pressure of metamorphism from area to area. Metamorphic grade boundaries are drawn using the classification scheme of Winkler (1979). All boundaries that are shown in the quadrangle are approximate and gradational.

Metamorphic rocks in the quadrangle are broadly grouped into three categories based upon temperatures reached during metamorphism. These categories are very low grade, low grade, and low to medium grade. Very low-grade and low-grade metamorphic rocks constitute the regionally metamorphosed rocks in the quadrangle and are equivalent to the greenschist facies (Turner, 1968). Within areas of low-grade metamorphism, rocks that were metamorphosed under relatively highpressure conditions are distinguished by the glaucophane zone, and rocks that were metamorphosed under relatively high temperature are distinguished by the garnet zone. A third category, low- to medium-grade metamorphic rocks, consists of those affected by contact metamorphism near granitic plutons. Rocks shown as contact metamorphic on figure 3 correspond to the albite-epidote-hornfels facies or hornblendehornfels facies of Turner (1968).

\section{VERY LOW-GRADE METAMORPHIC ROCKS}

Metamorphic rocks designated as very low grade occur in the foothills of the Baird and Schwatka Mountains bordering the Kobuk and Noatak River valleys. Most rocks show only partial recrystallization. Fine-grained clastic rocks are slate, and mafic rocks are recognizable in hand specimen as basalt or diabase. Petrographic study of the mafic igneous rocks commonly reveals relict and corroded phenocrysts of augite. Common mineral assemblages include quartz, chlorite, calcite, kaolinite, and pumpellyite. In the Ambler River quadrangle, the mineral most diagnostic of this facies is pumpellyite, which occurs only in mafic igneous rocks or wacke that was, in part, derived from mafic rocks.

\section{LOW-GRADE METAMORPHIC ROCKS}

Low-grade metamorphic rocks make up most of the Baird and Schwatka Mountains and also crop out in the core of the Cosmos Hills antiform. Rocks that are believed originally to have been shale show a range of recrystallization from gray phyllite to fine-grained quartz-mica schist. Common mineral assemblages in metasedimentary rocks include quartz, albite, muscovite, chlorite, calcite, tourmaline, and chloritoid. Typical mineral assemblages in metamafic rocks include actinolite, sphene, albite, stilpnomelane, and clinozoisite.

Within the broad area of low-grade metamorphic rocks, the glaucophane zone, indicative of relatively high pressure, and the garnet zone, indicative of relatively high temperature, are also shown on figure 3. They are characterized as follows:

Glaucophane zone.-The glaucophane zone of low-grade metamorphic rocks occurs mainly along a discontinuous linear trend in the central and eastern part of the schist belt. Common minerals are glaucophane or crossite, clinozoisite, stilpnomelane, garnet, paragonite, and rare jadeite 


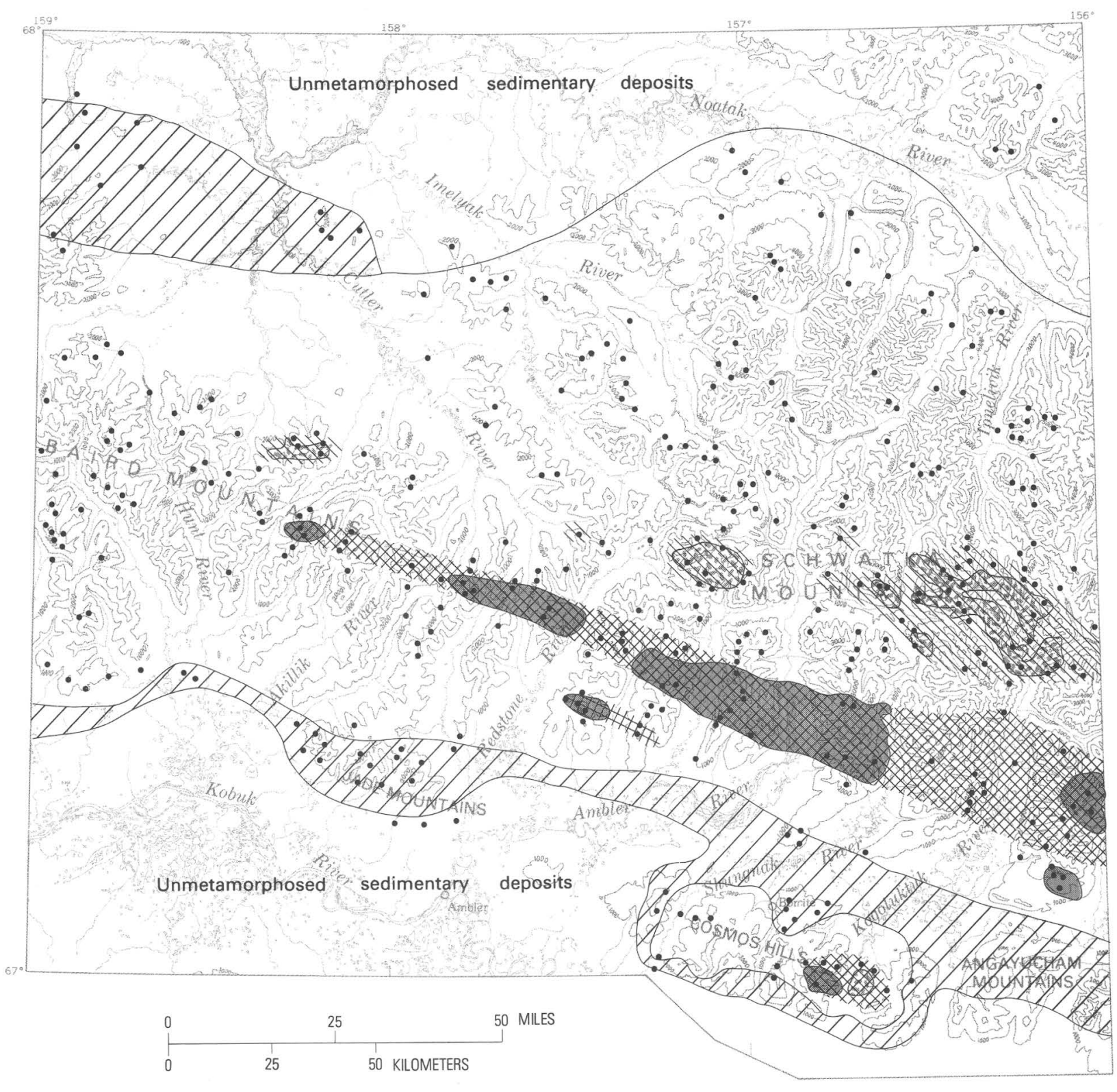

EXPLANATION
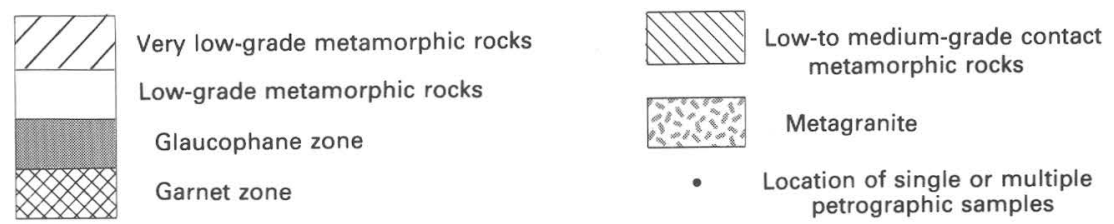

FIGURE 3.-Metamorphic boundaries in the Ambler River quadrangle and the northeastern part of the Shungnak quadrangle.

(Forbes and others, 1974; Gilbert and others, 1977; Carden, 1978). These minerals are found discontinuously in both metasedimentary and metamafic rocks. Glaucophane almost everywhere shows some degree of retrograde alteration to the common minerals of the low-pressure, low-grade meta- morphic rocks. It is likely that in many areas, glaucophane and jadeite were completely retrograded to lower-pressure mineral assemblages and that the area affected by high-pressure metamorphism was more extensive than is shown on figure 3 . The glaucophane zone of metamorphic rocks 
(fig. 3) in the Cosmos Hills is in doubt. Tailleur collected glaucophane from a metamorphic float cobble that he believes came from a nearby outcrop, but an attempt by Carden (1978) to recollect glaucophane from outcrops in the vicinity was unsuccessful. It is possible the sample was of glacial origin which, if true, would nullify the evidence for the glaucophane zone in the Cosmos Hills.

Garnet zone.-The garnet zone, especially almandine-rich garnet, is indicative of the higher temperature part of low-grade metamorphism. This mineral occurs in metasedimentary and metamafic rocks along a northwest trend in the central part of the schist belt where regional metamorphism was greatest. This zone mostly overlaps the glaucophane zone, but it is more extensive, perhaps because garnet is more stable to retrograde metamorphism at lower pressures than is glaucophane. There is a gradual transition to lower temperature mineral assemblages and smaller mineral grain size of micaceous minerals both to the north and south. Typical mineral assemblages in metasedimentary rocks include quartz, albite, muscovite, chlorite, clinozoisite, garnet, tourmaline, chloritoid, and rare biotite. Metamafic rocks commonly contain green hornblende, garnet, albite, epidote, chlorite, and sphene. In most areas, almandine-spessartine garnet is a common and conspicuous mineral. It occurs as large poikilitic and locally helicitic crystals, many of which are partly or completely altered to chlorite or biotite. In the Cosmos Hills, garnetiferous metasedimentary rocks are dispersed in a wide band around metamorphosed granitic rock cropping out in the Kogoluktuk River valley. This relation suggests that the granitic rock may have produced a thermal halo during metamorphism.

\footnotetext{
LOW- TO MEDIUM-GRADE CONTACT METAMORPHIC ROCKS
}

Most contact metamorphic rocks in the quadrangle occur as thin discontinuous hornfels or tactite zones at the borders of a linear trend of granitic plutons north of the most highly recrystallized regionally metamorphosed rocks. Most tactites show some degree of foliation, but in a few localized zones, they appear to be unaffected by dynamothermal metamorphism. In detail, hornfels or tactite zones occur only locally in the areas that are shown as contact metamorphic in figure 3 .
Typical mineral assemblages include diopside, wollastonite, garnet, andalusite, tremolite, and biotite. These minerals indicate relatively low pressure conditions and temperatures indicative of both low and medium grades of metamorphism (Winkler, 1979).

HISTORY OF METAMORPHISM

The metamorphic history of the rocks in the Ambler River quadrangle is complex because there is evidence that metamorphism occurred in the middle Paleozoic, Cretaceous, and possibly the late Precambrian. Most geologists who have studied the metamorphic rocks in the Ambler River quadrangle agree that a regional metamorphic event affected the southern Brooks Range in the early and middle Cretaceous, about 130-80 m.y. ago. This concept is strongly supported by the stratigraphic record of regional tectonism at this time and by many potassium-argon dates from metamorphic micaceous minerals in the schists and gneisses (Turner and others, 1979a). Metamorphism probably accompanied downwarping of the south edge of the Alaska Arctic plate as imbricated thrust sheets were stacked above the rocks in the central part of the quadrangle (Gealey, 1980). Later isostatic rebound and erosion of the crustal welt in the southern Brooks Range have exposed these metamorphic rocks throughout the Baird and Schwatka Mountains.

Other radiogenic evidence dates the period of contact metamorphism that coincided with the intrusion of granitic plutons in the central part of the quadrangle during the middle Paleozoic (Dillon and Gilbert, 1978; Nelson and others, 1979). These data are supported by the stratigraphic record of a late Devonian uplift, probably accompanied by block faulting, in the Schwatka Mountains terrane (fig. 2) where the early Mississippian Kekiktuk Conglomerate appears to overlie Devonian and older rocks with an angular unconformity (Mull and Tailleur, 1977; Mayfield and Tailleur, 1978). Although the details of the late Devonian uplift are sketchy, there appears to be little evidence that the period of contact metamorphism coincided with a regional dynamothermal metamorphic event.

Scattered potassium-argon metamorphic mineral ages in the Precambrian and Paleozoic suggest to Turner and others $(1979 a, b)$ that the 
southern Brooks Range was affected by an earlier period of regional high-pressure metamorphism that produced the glaucophane mineral assemblages in the late Precambrian. These data are supported by textural evidence from the metamorphic minerals which indicates that glaucophane and jadeite crystallized at an early stage in the metamorphic process and were later retrograded to lower pressure mineral assemblages (Forbes and others, 1974; Mayfield, 1976; Gilbert and others, 1977; Carden, 1978). The interpretation of a late Precambrian metamorphic event in some rocks of the schist belt terrane (fig. 2) is complicated by the fact that all the rocks of this area were metamorphosed in the Cretaceous age. Some of the alleged Precambrian glaucophane-bearing rocks occur in the volcanogenic copper belt (fig. 2) closely associated with middle Paleozoic igneous and sedimentary rocks. Wiltse and Gilbert (1977) believe that the middle Paleozoic rocks were deposited unconformably upon a Precambrian basement, and during the Cretaceous regional metamorphism, the Precambrian and Paleozoic rocks became tectonically intercalated (Gilbert and others, 1977). Other geologists remain skeptical of these interpretations, which are based on mapping and sampling in an area of rocks that is recrystallized and isoclinally folded. To the west in the Baird Mountains quadrangle where the rocks are not so strongly recrystallized, glaucoplane has been found in mafic igneous rocks lying between homoclinally dipping fossiliferous middle Paleozoic limestones $\left(67^{\circ} 25^{\prime}\right.$ latitude, $162^{\circ} 35.5^{\prime}$ longitude). Nearby mafic igneous rocks, which appear similar to those with glaucophane, have intruded the limestones. If these relations are interpreted correctly, field observations require the unlikely geographic coextension of two separate glaucophane events, one that occurred in the late Precambrian and one that occurred after the middle Paleozoic. Reconciling the field observations with the Precambrian radiogenic age dates remains an important unresolved problem concerning the metamorphic rocks in the south-central and southwestern Brooks Range.

\section{POTASSIUM-ARGON AGES}

All potassium-argon ages in the quadrangle are located on figure 4 and listed in table 2. Most dates previously reported in various other publications are summarized by Turner and others (1978; 1979a). Ages from localities 26 and 27 are published here for the first time. The potassium-argon date from locality 27 may represent a minimum age for detrital muscovite in a feldspathic wacke rock unit. Since all the other ages are from rocks partly or completely recrystallized by metamorphism, the minerals that were dated either formed under metamorphic conditions or had their radiogenic constituents affected by a later metamorphism.

Study of table 2 reveals a wide spread of potassium-argon ages ranging from Precambrian to Cretaceous. Almost all ages obtained from muscovite and biotite fall in the Cretaceous between 130 and 88 m.y. These dates are believed to reflect the last stage of regional metamorphism in the area which coincides with the period of most intense tectonic activity associated with the Brooks Range orogeny (Tailleur and Brosgé, 1970). Ages obtained from glaucophane and actinolitic hornblende present a much more complex and controversial picture. These amphibole ages range from 2,255 to $163 \mathrm{~m} . \mathrm{y}$. ago. Most preCretaceous ages cannot be taken at face value because there are too many instances where similar rocks located in a similar stratigraphic setting give widely divergent ages. Glaucophane samples yielding ages greater than 1 b.y. are believed to have been affected by excess argon so that they represent values that are too old by an undetermined amount (Turner and others, 1979a). A group of potassium-argon ages in the 760 to $570 \mathrm{~m}$.y. range suggests that many of the rocks may have been subjected to a late Precambrian period of regional metamorphism. Under this hypothesis, the various Paleozoic and Mesozoic ages between 560 and 150 m.y. may represent partial argon loss due to the later Cretaceous metamorphic event. A more complete discussion of this idea is presented by Turner, Forbes, and Mayfield (1978) and Turner, Forbes, and Dillon, (1979a, b).

\section{URANIUM-LEAD AGES}

$\mathrm{U}-\mathrm{Pb}$ ages from two duplicate samples are reported by Dillon and others (1979); Dillon and others (1980) using the mineral zircon separated from blastoporphyritic schist (informally called the "button schist" by some geologists) and collected at the Arctic deposit in the volcanogenic 


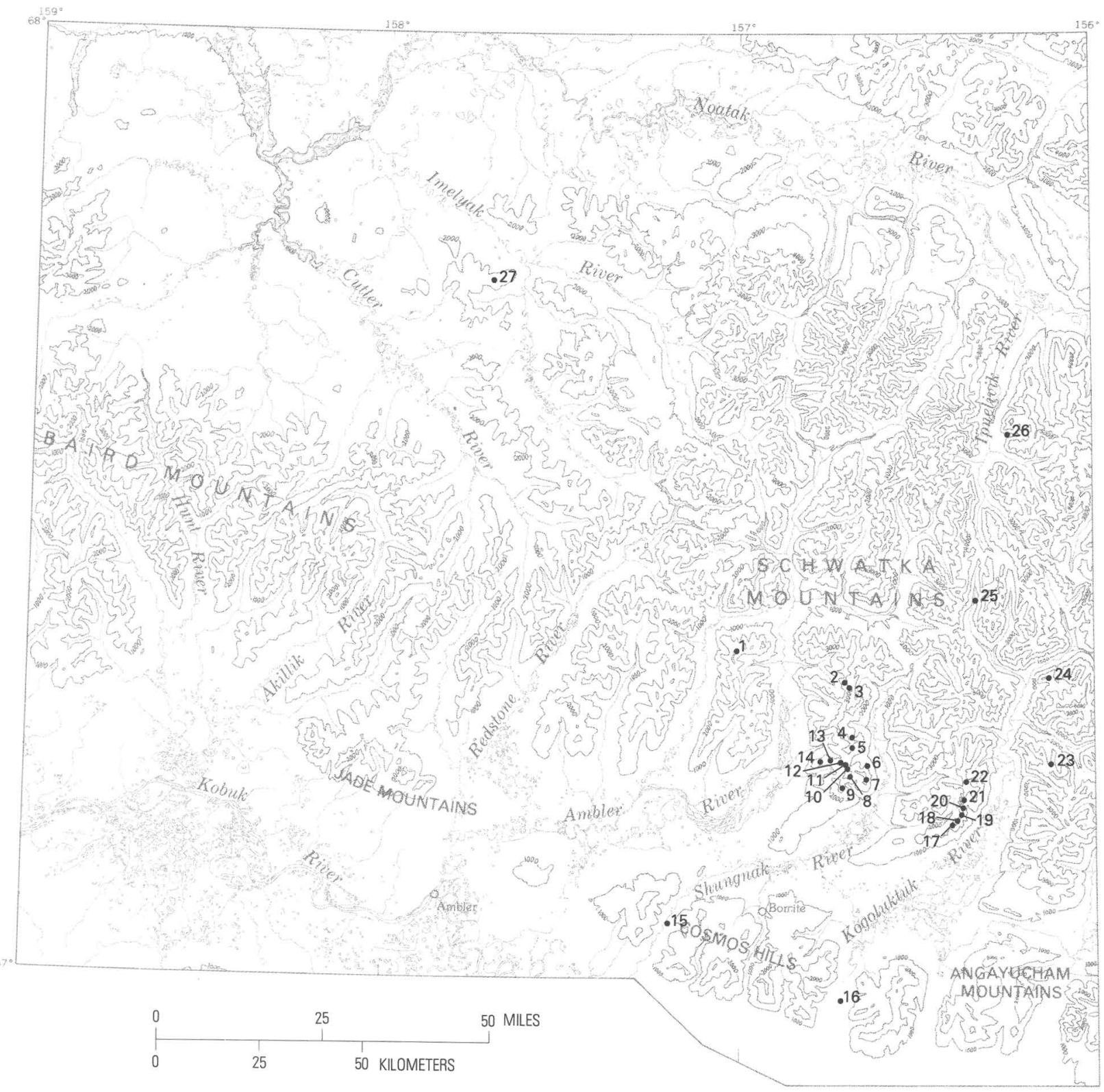

FIGURE 4.-Location of rocks that have been dated by radiogenic methods in the Ambler River quadrangle and the northeastern part of the Shungnak quadrangle. Numbers refer to listings in tables 2, 3, and 4.

copper belt (table 3 and fig. 4). The ages from these samples, when combined with U-Pb ages from other similar granitic and rhyolitic rocks east of the Ambler River quadrangle, form a chord on a ${ }_{206} \mathrm{~Pb} /{ }_{238} \mathrm{U}$ diagram that intersects concordia at about $360 \mathrm{~m} . \mathrm{y}$. and $80 \mathrm{~m} . \mathrm{y}$. The intersections of the chord of the U-Pb dates and the concordia curve are interpreted by Dillon to indicate an approximate late Devonian crystallization age for the zircons in the copper belt volcanic rocks and an episodic lead loss from zircon sometime between the Devonian and the end of Cretaceous regional metamorphism. Smith and others (1978) also report Paleozoic model lead ages, ranging from 350 to $250 \mathrm{~m}$.y., from the sulfide samples in metavolcanic rocks in the volcanogenic copper belt (fig. 2).

\section{LEAD-ALPHA AGES}

Two lead-alpha dates have been determined using zircon separated from metagranites, one from 


\begin{tabular}{|c|c|c|c|c|c|c|c|}
\hline $\begin{array}{l}\text { Location } \\
\text { No. on } \\
\text { figure } 4 \text { Sample no. }\end{array}$ & Source & Rock type & Mineral dated & $\begin{array}{c}\text { Average } \mathrm{K}_{2} \mathrm{O} \\
\text { (weight percent) }\end{array}$ & $\begin{array}{c}{ }^{40} \mathrm{Ar}_{\mathrm{rad}} \\
(\mathrm{mol} / \mathrm{g}) \times 10^{-11}\end{array}$ & $\begin{array}{l}{ }^{40} \mathrm{Ar}_{\mathrm{rad}} \\
\text { (percent) }\end{array}$ & $\begin{array}{l}\text { Age in } \\
\text { million } \\
\text { years plus } \\
\text { or minus } \\
\text { analytical } \\
\text { uncertainty }\end{array}$ \\
\hline $1-----72 E 100 R$ & $\begin{array}{l}\text { Turner and } \\
\text { others (1978; } \\
\text { 1979a) }\end{array}$ & $\begin{array}{l}\text { Quartz } \\
\text { muscovite } \\
\text { schist }\end{array}$ & Muscovite & 10.245 & 197.4 & 93.1 & $129 \pm 3.9$ \\
\hline $2------73 R R 75-3$ & do & $\begin{array}{l}\text { Actinolite } \\
\text { schist }\end{array}$ & $\begin{array}{l}\text { Impure } \\
\text { actinolite }\end{array}$ & .071 & 3.973 & 64.1 & $352 \pm 17.7$ \\
\hline $3------74$ AWM309 & do & $\begin{array}{l}\text { Actinolite } \\
\text { quartz } \\
\text { chlorite } \\
\text { schist }\end{array}$ & Actinolite & .075 & 5.335 & 49.9 & $435 \pm 30.5$ \\
\hline $5------73 R R 54$ & do & $\begin{array}{l}\text { Garnet } \\
\text { glaucophane } \\
\text { schist }\end{array}$ & Glaucophane & .037 & 15.08 & 81.7 & $1,694 \pm 85$ \\
\hline $6----72 \mathrm{E} 56 \mathrm{~B}$ & do & $\begin{array}{l}\text { Biotite } \\
\text { muscovite } \\
\text { schist }\end{array}$ & Muscovite & 11.000 & 307.2 & 88.1 & $184 \pm 5.5$ \\
\hline $7------C-2$ & do & $\begin{array}{l}\text { Garnet } \\
\text { glaucophane } \\
\text { schist }\end{array}$ & Glaucophane & .044 & 12.60 & 86.9 & $1,338 \pm 134$ \\
\hline $10------73 R R 7 G$ & do & $\begin{array}{l}\text { Glaucophane } \\
\text { quartz } \\
\text { muscovite } \\
\text { schist }\end{array}$ & $\begin{array}{l}\text { Glaucophane } \\
\text { Muscovite }\end{array}$ & $\begin{array}{r}.038 \\
5.061\end{array}$ & $\begin{array}{c}3.867 \\
96.31\end{array}$ & $\begin{array}{l}52.5 \\
65.1\end{array}$ & $\begin{array}{l}597 \pm 59 \\
128 \pm 4\end{array}$ \\
\hline $11-----73 R R 6 E F$ & do & $\begin{array}{l}\text { Biotite } \\
\text { feldspar } \\
\text { quartz } \\
\text { muscovite } \\
\text { schist }\end{array}$ & $\begin{array}{l}\text { Biotite (I) } \\
\text { Biotite (II) } \\
\text { Muscovite }\end{array}$ & $\begin{array}{r}9.530 \\
9.530 \\
11.197\end{array}$ & $\begin{array}{l}147.2 \\
149.2 \\
190.2\end{array}$ & $\begin{array}{l}88.8 \\
93.4 \\
92.8\end{array}$ & $\begin{array}{l}105 \pm 3 \\
106 \pm 3 \\
115 \pm 3\end{array}$ \\
\hline $12----73 R R 18 F$ & do & $\begin{array}{l}\text { Biotite quartz } \\
\text { muscovite } \\
\text { schist }\end{array}$ & $\begin{array}{l}\text { Biotite } \\
\text { Muscovite }\end{array}$ & $\begin{array}{r}9.118 \\
10.837\end{array}$ & $\begin{array}{l}180.0 \\
210.3\end{array}$ & $\begin{array}{l}91.0 \\
84.9\end{array}$ & $\begin{array}{l}132 \pm 4 \\
130 \pm 4\end{array}$ \\
\hline $13-----A-1$ & do & $\begin{array}{l}\text { Garnet } \\
\text { glaucophane } \\
\text { schist }\end{array}$ & $\begin{array}{l}\text { Glaucophane (I) } \\
\text { Glaucophane (II) } \\
\text { Glaucophane (III) }\end{array}$ & $\begin{array}{l}.012 \\
.012 \\
.012\end{array}$ & $\begin{array}{l}9.581 \\
9.530 \\
9.570\end{array}$ & $\begin{array}{l}45.4 \\
67.2 \\
63.2\end{array}$ & $\begin{array}{l}2,535 \pm 507 \\
2,555 \pm 511 \\
2,535 \pm 507\end{array}$ \\
\hline A-1CNM & do & $\begin{array}{l}\text { Garnet } \\
\text { glaucophane } \\
\text { schist }\end{array}$ & Paragonite & .430 & 15.86 & 32.2 & $239 \pm 7$ \\
\hline
\end{tabular}




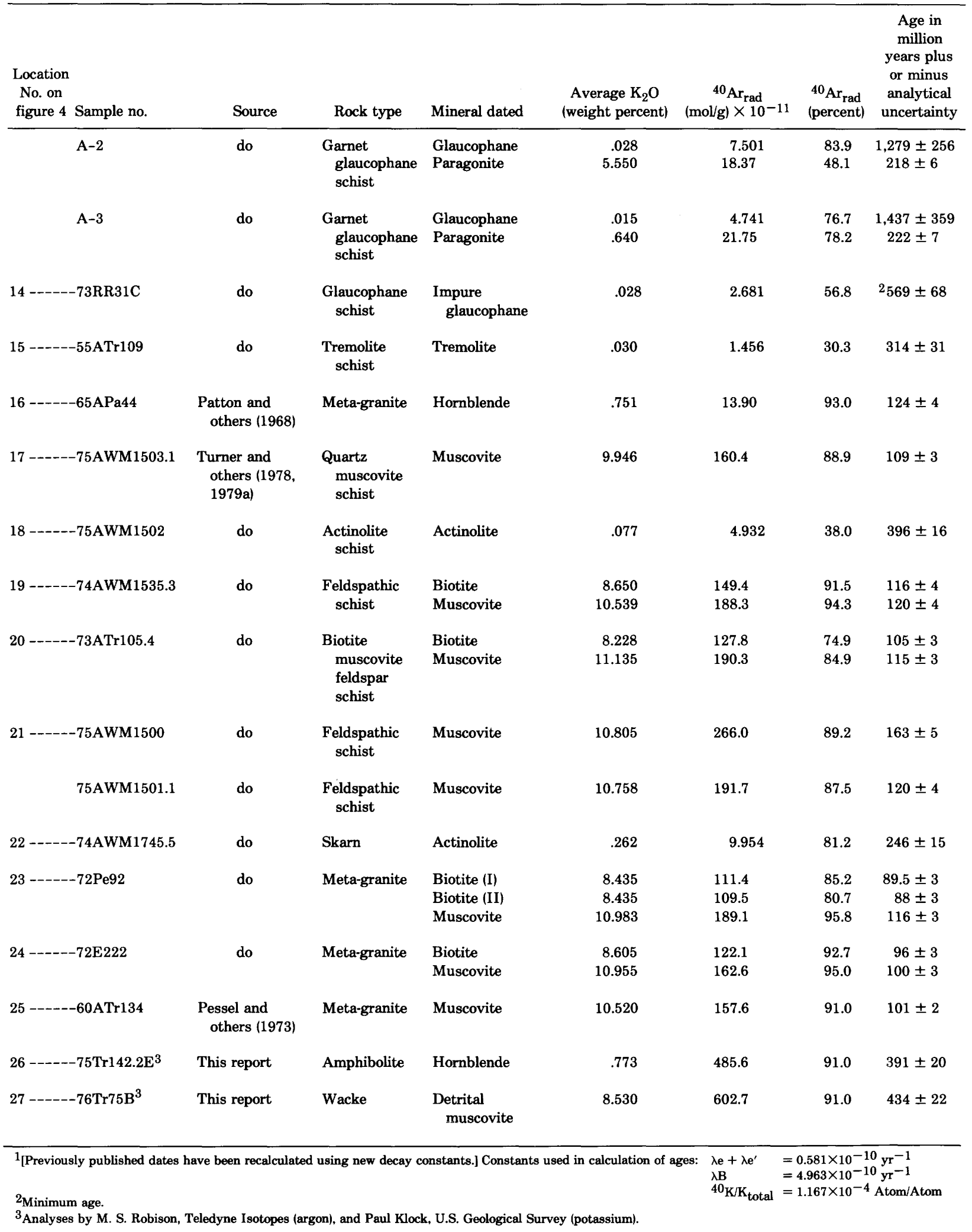


TABLE 3.-Uranium-lead ages from the Ambler River quadrangle

\begin{tabular}{|c|c|c|c|c|c|c|c|}
\hline \multirow{2}{*}{$\begin{array}{l}\text { Location No. } \\
\text { on figure } 4\end{array}$} & \multirow[b]{2}{*}{ Sample no. } & \multirow{2}{*}{$\begin{array}{c}\text { First } \\
\text { publication }\end{array}$} & \multirow[b]{2}{*}{ Rock type } & \multirow{2}{*}{$\begin{array}{l}\text { Mineral } \\
\text { dated }\end{array}$} & \multicolumn{3}{|c|}{ Ages (m.y.) } \\
\hline & & & & & ${ }^{206} \mathrm{~Pb}^{*} /{ }^{238} \mathrm{U}$ & ${ }^{207} \mathrm{~Pb} * / / 235 \mathrm{U}$ & ${ }^{207} \mathrm{~Pb} * / 206 \mathrm{~Pb}$ \\
\hline $20--------$ & 77DN76 & $\begin{array}{l}\text { Dillon and } \\
\text { Pessel, } 1979\end{array}$ & $\begin{array}{l}\text { Blastoporphyritic } \\
\text { schist }\end{array}$ & Zircon & 329 & 334 & 373 \\
\hline $20-$ & $77 \mathrm{Mw} 76$ & do & do & do & 327 & 332 & 364 \\
\hline
\end{tabular}

the Cosmos Hills and the other from the upper Kogoluktuk River near Schishakshinovik Pass (table 4 and fig. 4). These ages were determined in 1960 and 1961 during the early years of lead isotope dating techniques and therefore should not be used as specific dates, because it is probable that lead and uranium gain or loss has affected the ages by an indeterminable amount. However, these dates suggest that the metagranites are preCretaceous in age, especially in light of more recent U-Pb dates (Dillon and others, 1979) and RbSr dates (Nelson and others, 1979) from similar granitic rocks in the Survey Pass quadrangle.

\section{FOSSIL LOCALITIES}

Outcrops where fossils have been collected are shown on figure 5 , and a list of the type of fossil(s), age, and geologic rock unit in which they were found is given in table 5. Fossil ages range from Ordovician to Mississippian. Most fossils come from partially recrystallized carbonate rocks mapped as the Baird Group, Skajit Limestone, Lisburne Group, and various small unnamed limestone beds within clastic rock units. A detailed discussion of Paleozoic corals from collections in carbonate rocks in the southern part of the quadrangle is reported in Oliver and others (1975). Conodonts identified from the northern part of the quadrangle have color alteration indexes. of 5$51 / 2$, indicating postdepositional temperatures of $300^{\circ}-400^{\circ} \mathrm{C}$. The only fossils which have been found in non-carbonate rocks are Silurian graptolites from dark-gray slates in the northwestern part of the quadrangle.

\section{COMPONENT MAPS OF THE AMBLER RIVER QUADRANGLE FOLIO}

GEOLOGY REPORT OF 78-120-A

The first component of the Ambler River folio is the geologic map published at 1:250,000 scale, and a generalized version appears on the base maps for many of the other folio components. Most rocks in the quadrangle have been tectonically disturbed and metamorphosed to such an extent that fossil evidence has been obliterated from many of the rock units, thus making it difficult to construct a complete stratigraphic column. Without a coherent stratigraphic column, many of the major folds and faults in the quadrangle are unrecognized. To enable the reader of the map to understand the degree of uncertainty attached to the age of various map units, sedimentary and metasedimentary rocks are divided into categories of certain and uncertain age. Among the rocks of uncertain age, some are given queried systemic age assignments usually based on tenuous correlations with other rocks located some distance away, commonly outside the quadrangle.

TABLE 4.-Lead-alpha ages from the Ambler River quadrangle

[Lead-alpha determinations by T. W. Stern 1960-61]

\begin{tabular}{|c|c|c|c|c|c|c|c|}
\hline $\begin{array}{l}\text { Location No. } \\
\text { on figure } 4\end{array}$ & Sample no. & $\begin{array}{c}\text { First } \\
\text { publication }\end{array}$ & Rock type & $\begin{array}{c}\text { Mineral } \\
\text { dated }\end{array}$ & $\alpha / \mathrm{mg}-\mathrm{hr}$ & $\mathrm{Pb}(\mathrm{ppm})$ & Age (m.y.) \\
\hline $25--------$ & $60 \mathrm{ATr} 134$ & This report & Metagranite & Zircon & 1,236 & 105 & $210 \pm 25$ \\
\hline $16 \ldots$ & 55ATr149 & do & do & do & 2,125 & 420 & $490 \pm 60$ \\
\hline
\end{tabular}




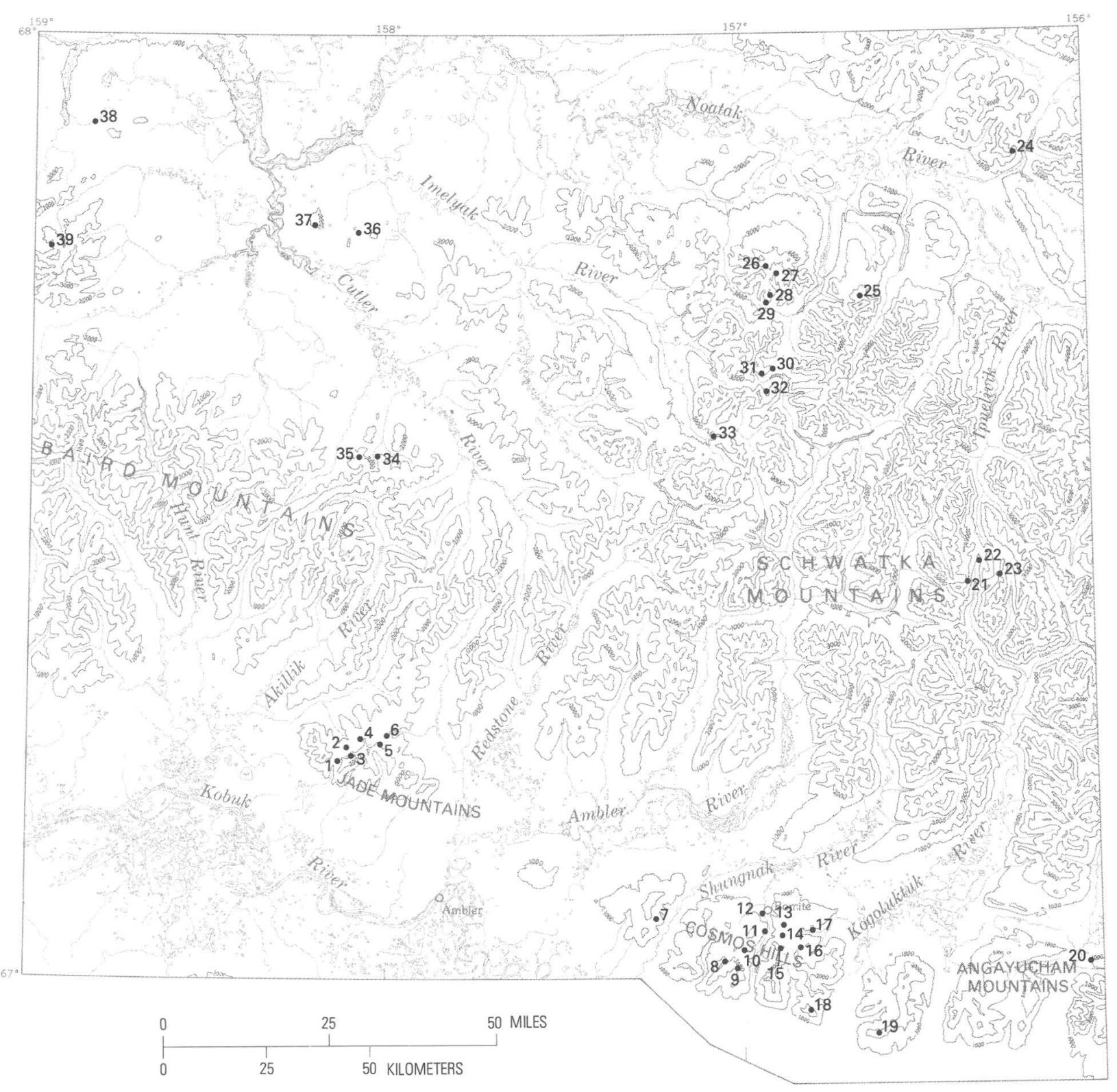

Figure 5.-Fossil localities in the Ambler River quadrangle and the northeastern part of the Shungnak quadrangle. Numbers refer to listing in table 5.

Since the publication of the geologic map, radiogenic age dating work on some granitic rocks in the Ambler River and adjacent Survey Pass quadrangles shows strong evidence that the time of igneous cooling of both rhyolitic metavolcanic rocks in the southeastern part of the quadrangle and the granitic metaplutonic rocks stretching across the central part of the quadrangle is middle Paleozoic. Dillon and Gilbert (1978) have determined that the megacrystic felsic schist in the Ambler River quadrangle is approximately 360 m.y. old by U-Pb dating methods on zircon. Recent dates from granitic plutonic rocks in the central part of the Survey Pass quadrangle by Nelson and others (1979) using Rb-Sr methods and by Dillon and Gilbert (1978) using U-Pb methods also support a middle Paleozoic age for these rocks. Because the granitic plutonic rocks stretching across the central part of the Ambler River quadrangle are mineralogically similar and crop out on the same linear belt, they are also probably middle Paleozoic. These rocks are shown on the map as Cretaceous, 
TABLE 5.-Fossils collected in the Ambler River quadrangle

[Field samples listed as Lehner, Babcock, Read, and Bornite are from collections of Bear Creek Mining Co.; sample numbers beginning with $69 \mathrm{~A}$ and 685 are from collections of Alaskan Division of Mines and Geology (Fritts, 1969a; 1970); and remaining samples are from the collections of the U.S. Geological Survey. The geologic units are on the geologic map of Mayfield and Tailleur (1978)]

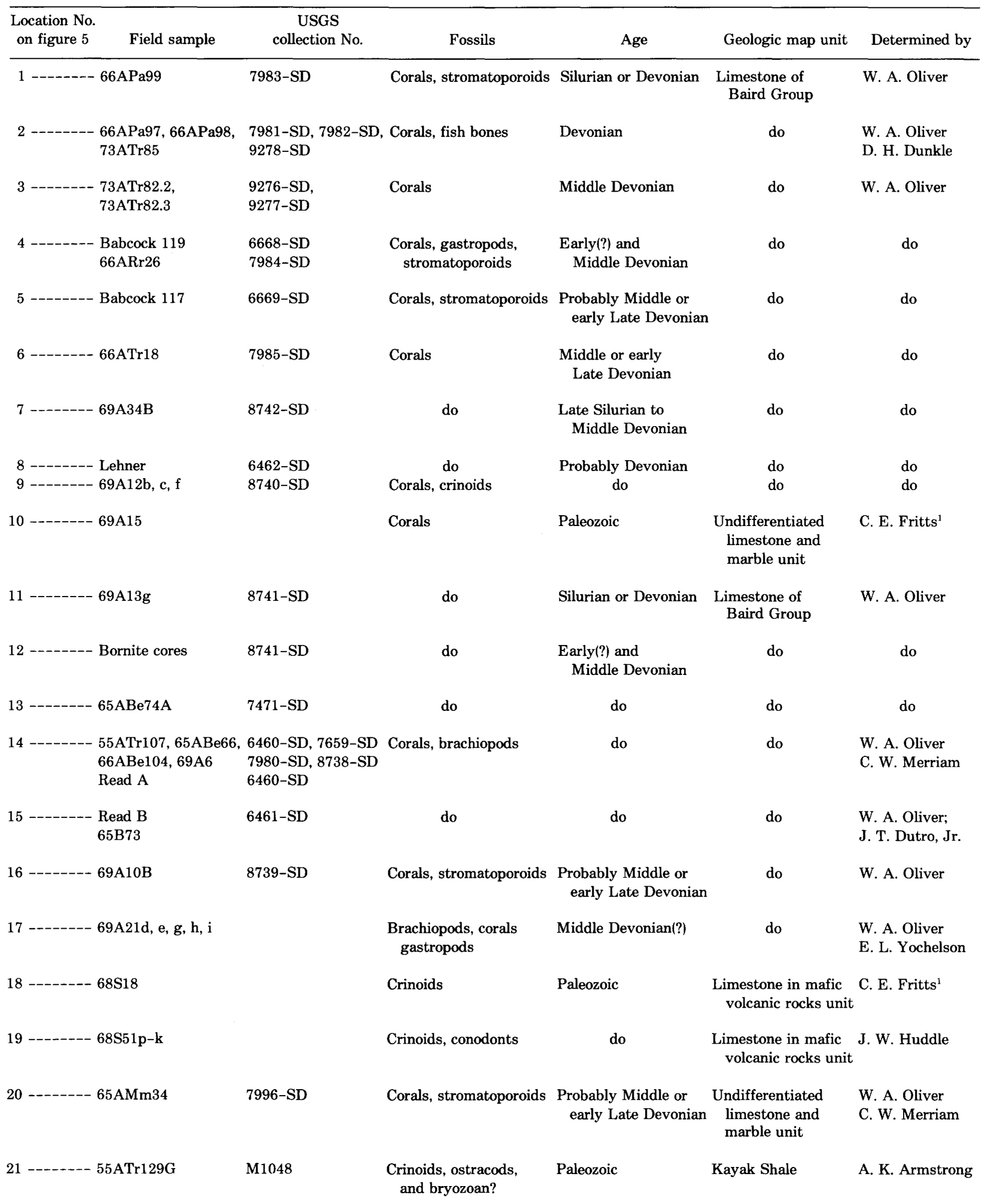


TABLE 5.-Fossils collected in the Ambler River quadrangle-Continued

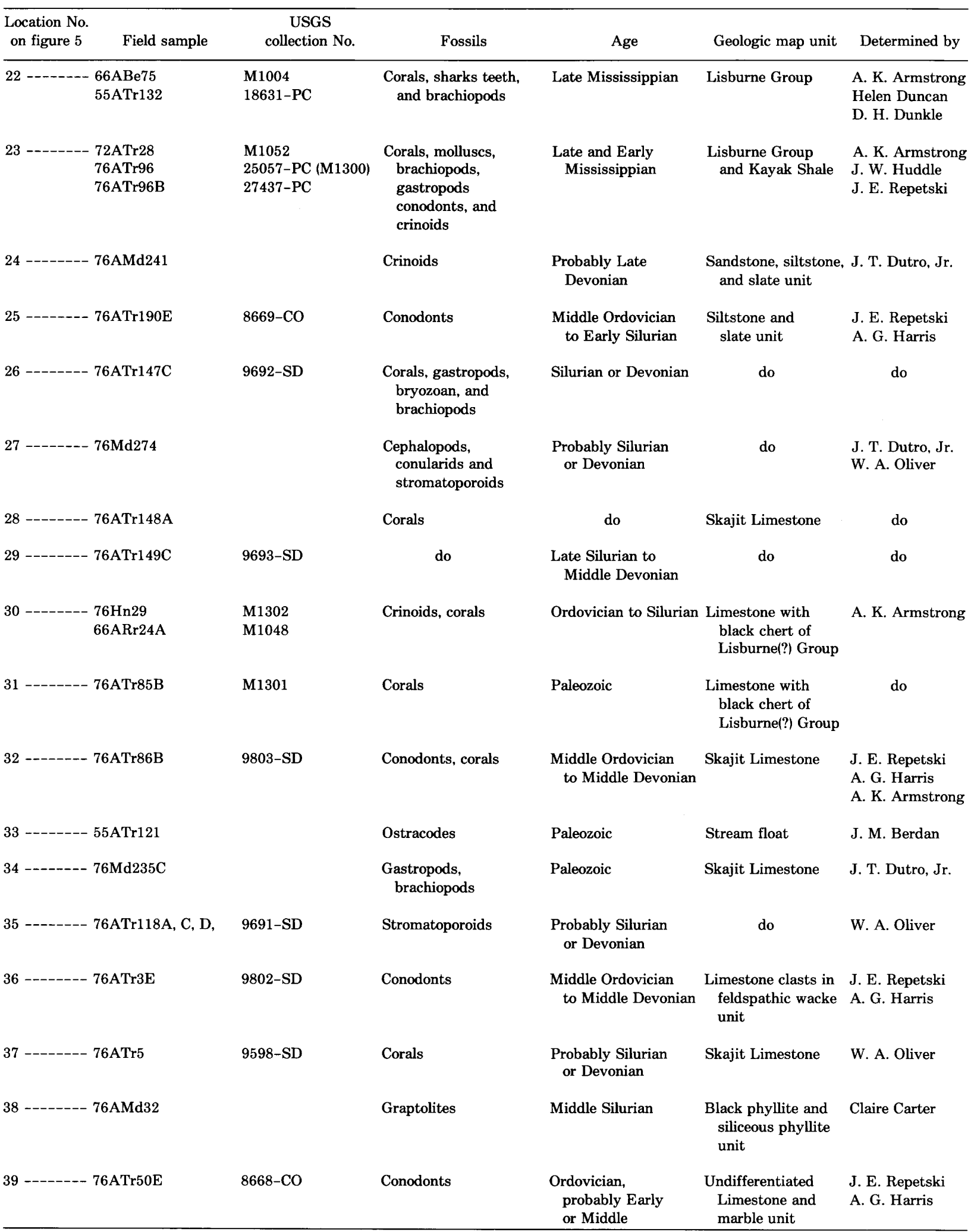

${ }^{1}$ Field identification by C. E. Fritts of Alaskan Division of Mines and Geology. 
but for the above-stated reasons are now regarded as probably being middle Paleozoic.

The geologic map of the Ambler River quadrangle shows only bedrock units. Those interested in geology of surficial deposits should consult the maps of Pessel and Brosgé (1977) and Fernald (1964).

RECONNAISSANCE GEOCHEMISTRY REPORTS OF 78-120-B THROUGH H

Geochemical studies in the Ambler River quadrangle were made to define areas of anomalous concentrations of selected metallic and nonmetallic elements. A sampling program was undertaken during the summer months of the years $1972,1973,1974$, and 1976, in which 1,281 streamsediment samples were collected, averaging about one sample per $9 \mathrm{~km}^{2}$ in areas where outcrops are exposed. This sampling density completes coverage of the quadrangle on a reconnaissance basis. Extensive Quaternary deposits which cover most of the Noatak and Kobuk valleys (about 25 percent of the quadrangle) were not sampled.

There are several previously published geochemical studies in the Ambler River quadrangle; most are incorporated into this folio. Three reports by the Alaska Division of Geological and Geophysical Surveys (Garland and Pessel, 1975; Garland and others, 1975; Pessel, 1976) present analyses of 657 stream-sediment samples from the Ambler River quadrangle. These samples have been included in the present compilation, along with 561 samples collected by the U.S. Geological Survey which are reported for the first time (OF 78-120-B, C). Two reports by Fritts $(1969 a ; 1970)$ are not included in this compilation. They present the analyses of 236 stream-sediment samples in the Cosmos Hills, including part of the Shungnak quadrangle adjacent to the Ambler River quadrangle. The samples were collected at 200- to 500-m intervals along a few creeks, a more concentrated and less uniform distribution than in the rest of the quadrangle. Some elements reported by Fritts have significantly higher median values than the values given in other reports on geochemistry of the Ambler River quadrangle, so these values are excluded from this compilation.

Samples were collected if possible from fine sediment in streams which drain bedrock. If no silt was present in the stream bed, samples were taken from alluvium on the bank or from around the roots of plants near the water's edge. The samples were sieved to retain the -80 mesh fraction, which was composed of clay and very fine silt. One split of each sample was analyzed by the atomic absorption method for copper, lead, and zinc. Samples collected in 1974 and 1976 were also analyzed for gold by the atomic absorption method. Another split of each sample was analyzed by the semiquantitative emission spectrographic method for 30 elements.

The analyses for the stream-sediment survey are listed by Ellersieck (1978a), and the sample locations are plotted on a generalized geologic map by Ellersieck (1978f). A threshold limit above which a sample is considered to be anomalous has been chosen for each element. These levels are determined entirely from data within the Ambler River quadrangle; therefore, they may be higher or lower than thresholds in other regions of different geology or stream chemistry. Because the data are reported in discrete analytical intervals, the distribution curve of elemental concentrations is not smooth, and the number of anomalous samples is different for each element. The proportion of anomalous samples may be as high as 9.8 percent (strontium) or as low as 0.7 percent (chromium); the average is 3.5 percent of the total number of samples.

There are five geochemical anomaly maps in the folio (Ellersieck, 1978b, c, d, e, g) which show the location of anomalies for the following 12 elements: copper, molybdenum, lead, zinc, barium, silver, arsenic, tin, beryllium, chrome, nickel, and cobalt. These elements were chosen either because they are of possible economic significance or because they appear to be related to the types of mineral deposits that could be found in the quadrangle.

An estimate of the effectiveness of the sample density of this survey can be made by calculating the percentage of known mineral occurrences that have a geochemical sample site within $5 \mathrm{~km}$ downstream and are reflected by anomalously high geochemical sample values for any of the commodities reported in the occurrence. Occurrences in the Cosmos Hills, nonmetallic mineral occurrences, claims, and occurrences that were determined to exist on the basis of the stream-sediment survey are excluded from consideration. Of the 53 mineral occurrences in the area of the geochemical survey, 39 (74 percent) had at least one stream-sediment sample within $5 \mathrm{~km}$ downstream. Of these $39 \mathrm{oc}-$ 
currences, 25 (64 percent or 47 percent of the 53 total occurrences) showed anomalous concentrations of silver, copper, lead, zinc, or an element reported to be in the occurrence by Mayfield and Grybeck (1978). On the basis of these crude assumptions, less than half of the known mineral occurrences are reflected in stream-sediment samples with anomalously high values.

There are many reasons why sample density and sample techniques such as those used are not more effective in finding mineral occurrences. The "halo" of geochemically enriched stream sediments near a mineral deposit is dependent upon a number of complex factors. For example, some deposits may spread their geochemical signatures farther than others, or the principal commodities may be effectively sampled only by a panning technique (not used in this survey). Therefore, a survey of this type cannot be expected to locate significant numbers of specific undiscovered mineral occurrences; instead it is most valuable for delineating broad areas with favorable resource potential and a few specific stream drainages that deserve more detailed exploration.

\section{MINERAL OCCURRENCES AND RESOURCES REPORT OF 78-120-I}

The mineral occurrences and resources map of the Ambler River quadrangle is intended to show three important kinds of mineral information. First, it shows the known mineral occurrences in the quadrangle. Second, it provides a discussion of the important mineral resources. Third, it delineates areas within the quadrangle that have a high potential for discovery of certain types of deposits which could yield significant mineral resources.

There are 80 mineral occurrences in the quadrangle that were known to us at the time of publication of this map. The mineral occurrences are listed numerically in a table accompanying the map. Each numbered occurrence is located on the 1:250,000-scale map of the Ambler River quadrangle, and the principal mineral commodities of interest are shown at each location. In addition, the table provides information on the form and description of the occurrence, the status of development, and the source from which information was obtained.

The map includes a discussion of the known and potential mineral resources of the Ambler River quadrangle. The most important resources include copper, zinc, lead, and silver; these occur in volcanogenic and carbonate breccia-type deposits. Of the nine known volcanogenic deposits in the quadrangle, one has reserves of 30 million tons of 4 percent $\mathrm{Cu}, 5.5$ percent $\mathrm{Zn}, 1$ percent $\mathrm{Pb}$, and $54.1 \mathrm{~g} /$ ton $(15 \mathrm{oz} /$ ton $\mathrm{Ag})$, and the other eight are of unknown size and grade. The number of undiscovered deposits at or near the surface is estimated by using areas of favorable geology and geochemical anomalies. Grade and tonnage of possible undiscovered deposits are estimated using data compiled on Canadian volcanogenic deposits of Phanerozoic age. Table 6 shows a crude assessment of the number, grade, and tonnage of undeveloped and undiscovered volcanogenic deposits in the quadrangle. The volcanogenic deposits of this district are at an early stage of development by mining companies, and until more public information is available about the known deposits, the assessment given above should be regarded only as an initial estimate. No attempt is made numerically to assess the base metal resource in carbonate breccia deposits because reserves a the few known deposits are not publically available and the origin of these deposits is speculative. At the largest deposit of this type, Ruby Creek, the reserves are significant. The largest known deposits of jade in Alaska occur in the quadrangle. Though these deposits have a subordinate resource potential, they are expected to provide a steady supply of jade for many years.

The third aim of the mineral occurrences and resources map is to show areas which have high potential for future discoveries of deposits that could provide significant amounts of mineral resources. Four categories of these deposits are

TABLE 6.-Estimate of number, grade, and tonnage of volcanogenic deposits

\begin{tabular}{crr}
\hline $\begin{array}{c}\text { Chance } \\
\text { (percent) }\end{array}$ & metric tonnage & \multicolumn{1}{c}{ Grade $^{2}$} \\
\hline 95 & 200,000 & $\begin{array}{r}6-10 \text { percent combined } \mathrm{Cu}, \mathrm{Pb} \text {, } \\
\text { Zn, and Ag }\end{array}$ \\
55 & $1,000,000$ & do \\
12 & $10,000,000$ & do \\
2 & $100,000,000$ & do \\
\hline
\end{tabular}

\footnotetext{
${ }^{1}$ Crude estimate of number of undiscovered deposits

90 percent chance that there are 7 or more undiscovered deposits

50 percent chance that there are 10 or more undiscovered deposits

10 percent chance that there are 12 or more undiscovered deposits

${ }^{2}$ Estimate of probable grades of volcanogenic deposits
} 
delineated on the same map as the known mineral occurrences. These categories are (1) volcanogenic deposits, (2) carbonate breccia deposits, (3) black pyritic phyllite deposits, and (4) jade, podiform chromite, and asbestos deposits. An accompanying explanation for favorable mineral resource areas provides a list of the reasons for selection of the specific areas based on geologic, geochemical, geophysical, and telegeologic information available in other segments of the Ambler River folio. Without detailed exploration and drilling, it is impossible to ensure that all favorable areas shown will actually contain deposits.

\section{INTERPRETATION OF LANDSAT IMAGERY REPORT OF 78-120-J}

The interpretation of Landsat imagery of the Ambler River quadrangle was made by using a black-and-white Landsat mosaic (band 7) of the State of Alaska assembled by the U.S. Department of Agriculture and by using computerenhanced black-and-white and color Landsat imagery processed by the U.S. Geological Survey in Flagstaff, Ariz. The mosaic of the Ambler River quadrangle is made from parts of three scenes, 1707-21385 and 1707-21391, taken June 30, 1974, and 1758-21201, taken August 20, 1974. Color computer-enhanced maps include linearly stretched standard false-color, sinusoidally stretched falsecolor, and simulated natural color images. A blackand-white vertical first-derivative image was also used. Copies of these products are available at nominal cost from the EROS Data Center, Sioux Falls, S. Dak. (Albert, 1978). Detailed descriptions of the various computer enhancement techniques used in these images are given by Albert and Steele (1976a, b) and Condit and Chavez (1978).

Interpretation of Landsat imagery for this folio consists of the identification of straight, circular, and arcuate lineaments and iron-oxide colored areas plotted on 1:250,000-scale maps of the Ambler River quadrangle. It is hoped that some of these features may prove to be directly or indirectly related to important mineral deposits even though a consistent correlation between known deposits and sets of lineaments has not yet been found in this study.

A number of straight lineaments correspond to mapped faults, and some of these indicate that the faults may extend beyond their mapped limits. A major east-trending broad lineament zone was identified closely corresponding to the Kobuk Trench (Grantz, 1966) and partially corresponding to a regional magnetic discontinuity (Gilbert and others, 1977; Hackett, 1980).

In previous studies, most circular features have been spatially associated with igneous activity, whereas arcuate features have been spatially associated with either igneous activity or metamorphism (Albert and Steele, 1976b). A circular feature centered on metagranitic plutonic rocks, west of the Ambler River in the central part of the quadrangle, is the only obvious spatial correspondence between circular features and igneous phenomena observed in the Ambler River quadrangle. It is possible that Cretaceous regional metamorphism has overprinted and obscured arcuate lineaments related to granitic plutonism.

Many of the iron-oxide colored areas identified on Landsat imagery were observed in the field from aircraft. A substantial number of these occur within carbonate rock units, many of which have not received adequate follow-up exploration. Many of the carbonate rocks observed in the field showed some degree of iron-oxide staining, and most of these could not be identified on Landsat imagery. Several of the iron-oxide areas identified on Landsat imagery, however, correspond to known mineral occurrences and (or) to geochemical anomalies.

\section{AEROMAGNETIC MAP AND INTERPRETATION REPORT OF 78-120-K}

The aeromagnetic interpretation of the Ambler River quadrangle is compiled on three sheets: the aeromagnetic-contour map, the magnetic-lineament and anomaly-trend map, and the geologicinterpretation map. The contoured aeromagnetic map appears at 1:250,000 scale on sheet 1 . An aeromagnetic survey of the quadrangle and adjacent areas was flown by Geometrics of Sunnyvale, Calif., in 1974 and 1975 for the Alaska Department of Natural Resources. The magnetic data were collected along north-south flightlines spaced $1.6 \mathrm{~km}(1.0 \mathrm{mi})$ apart (west half) and $1.2 \mathrm{~km}$ $(0.75 \mathrm{mi})$ apart (east half) and from an altitude of $300 \mathrm{~m}(1,000 \mathrm{ft})$ above ground level. The aeromagnetic data were first released at 1:63,360 scale in 1975-1976 and subsequently compiled as a 1:250,000-scale aeromagnetic map of the southwestern Brooks Range by the Alaska Division of 
Geological and Geophysical Surveys (Hackett, 1977). Rugged topography and marginal weather conditions within the southwestern Brooks Range caused the surveying aircraft to diverge from the nominal flight altitude over some areas within the Ambler River quadrangle. For this reason, magnetic anomalies that have some appreciable or suspected topographic expression are noted on the interpretation maps.

A magnetic-lineament and anomaly-trend map (sheet 2) was prepared to assist in the geologic interpretation of the aeromagnetic data. Major lineaments exist and indicate that regional discontinuites in the magnetic rocks correlate with the gross geologic pattern and structural setting within the Ambler River quadrangle. Magnetic anomaly patterns coincide in part with many individual geologic terranes and assist in defining some of the bedrock geology at depth.

The geologic interpretation map (sheet 3 ) of the aeromagnetic data identifies major magneticlithologic units, their suspected strike and dip, and their relative strength of magnetization. The magnetic-lithologic units were assigned to individual anomalies and magnetic gradient changes on the basis of correlation with the known geology. The units were integrated from a spectrally colored copy of the aeromagnetic map, from the lineament and anomaly-trend map, from detailed and generalized geologic maps (Pessel and Brosgé, 1977; Mayfield and Tailleur, 1978), and from geologic observations and field notes by Fritts, 1969-1972, Pessel, 1972-1975, and Hackett, 1975-1978. Continuous zones of steepened magnetic gradients and abrupt truncation of magnetic anomalies and trends are interpreted as major discontinuites (faults, unconformities, or facies changes) that may have surface expression.

In addition to the magnetic-lithologic units, six major aeromagnetic terranes (fig. 6) are outlined according to characteristic regional anomaly patterns: the Kobuk lowlands, Jade MountainsCosmos Hills-Angayucham Mountains, Ambler lowland, southern Brooks Range schist belt, plutonic belt, and thrust belt. The Kobuk lowlands terrane is characterized by broad magneticanomaly patterns which indicate considerable and varied depth to magnetic basement. Localized high-intensity anomalies over the Waring Mountains in the southwest corner of the quadrangle may be caused in part by tilted east-trending mafic-ultramafic rocks that are overlain by Cretaceous clastic rocks. The Jade Mountains-Cosmos Hills-Angayucham Mountains terrane is characterized by sharp, high-amplitude anomalies related to south-southwestward-dipping slabs of mafic and ultramafic rocks. The Ambler lowlands terrane is characterized by a linear zone of nearly flat magnetic gradient which outlines a topographic depression. The northern boundary of this terrane in the eastern part of the quadrangle is formed by the Ambler magnetic lineament, which parallels the conjectural Kobuk fault zone (Grantz, 1966; Patton, 1973). The southern Brooks Range schist belt terrane is characterized by subdued and variable response. Anomalies with variable amplitudes of less than 40 gammas occur with irregular distribution over the metavolcanic rocks of the volcanogenic copper belt. A narrow, composite zone of high magnetic relief is associated with the Walker Lake lineament, a major fault or unconformity. Convergence of the Walker Lake lineament and the Ambler magnetic lineament may reflect a western plunge of the Kalurivik arch, a major anticlinal feature in the southeast part of the quadrangle. The plutonic belt terrane is characterized by low-amplitude anomalies over carbonate rocks and schist broken by large asymmetric negative anomalies associated with granitic plutonic rocks. High-intensity magnetic zones near granite contacts may be over contact aureoles. The thrust belt terrane is characterized by subdued magnetic signature with a few zones of large positive magnetic anomalies over possible mafic rocks or magnetite-rich chloritic schists in the Cutler River area.

The aeromagnetic anomalies, trends, and lineaments in the Ambler River quadrangle are believed to help outline the regional tectonic trends and assist in synthesizing the bedrock geology. Local magnetic anomalies, caused by bedrock exposures of magnetic rock units, are commonly underlain throughout the quadrangle by larger magnetic bodies and are appreciably influenced by the magnetism of the adjacent terranes. These anomalies represent composite sets of juxtaposed magnetic boundaries which complicate geologic interpretation. However, the regional aeromagnetic data do help to define some of the bedrock geology at depth, identify previously unmapped structural features, and aid in projecting suspected trends of mineral deposits. 


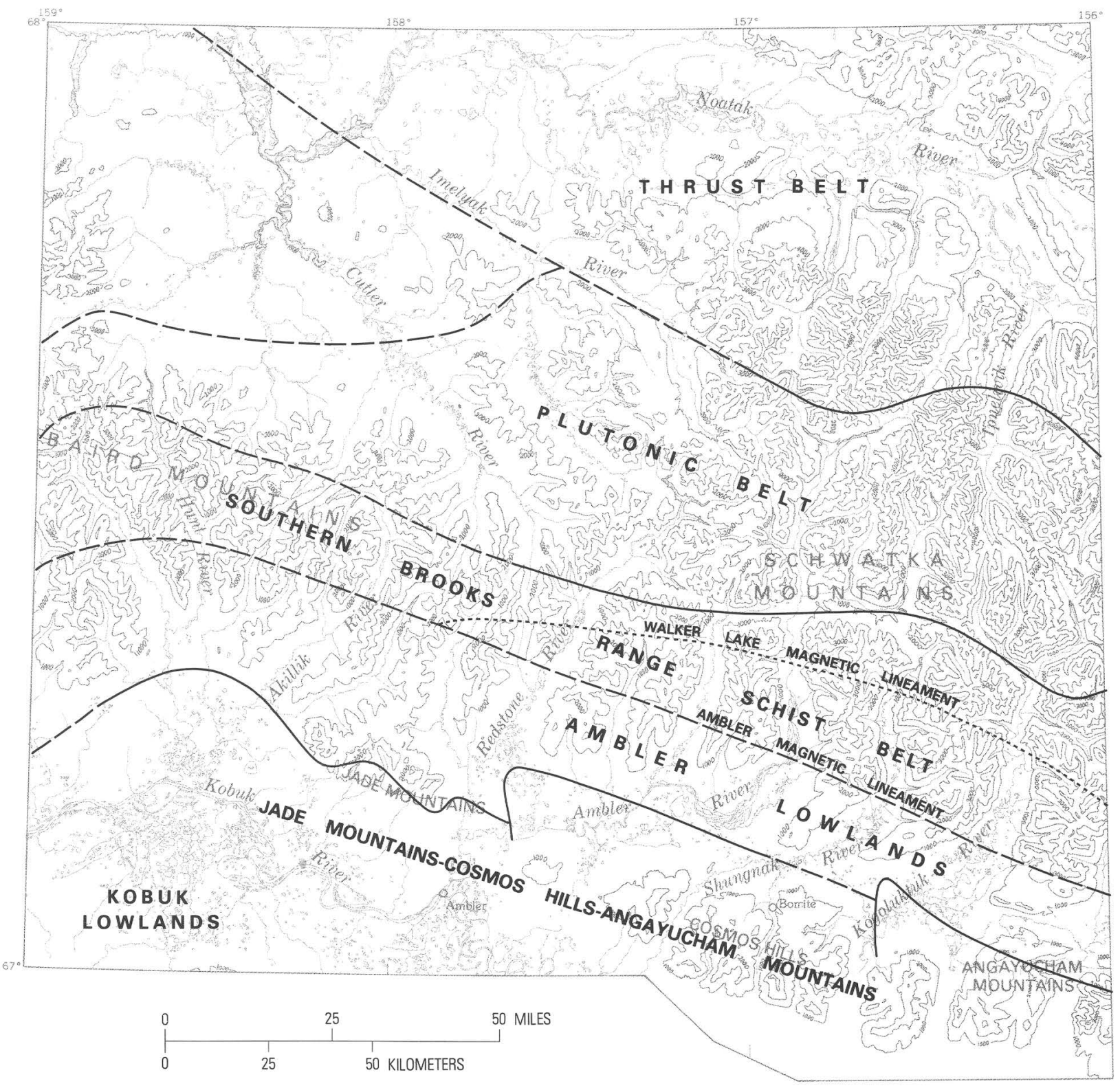

FIGURE 6.-Aeromagnetic terranes of the Ambler River quadrangle and the northeastern part of the Shungnak quadrangle.

\section{BIBLIOGRAPHY}

[References with asterisks $\left({ }^{*}\right)$ do not pertain directly to the Ambler River quadrangle but are cited in the text from general, regional, or topical studies.]

Aamodt, P. L., Hill, D. E., and Sharp, R. R., Jr., 1978, Uranium hydrogeochemical and stream sediment reconnaissance data from the area of the Noatak and portions of the Baird Mountains and Ambler River quadrangles, Alaska: Los Alamos, N. Mex., Los Alamos, Scientific Laboratory, University of California LA-6846-MS Informal Report GJBX-87 1978, 74 p.

Alaska Department of Mines, 1945, Report of the Commissioner of Mines for the biennium ended December 31, 1944; Juneau, Alaska, 48 p.
1946, Report of the Commission of Mines to the Governor for the two bienna ended December 31, 1946: Juneau, Alaska, $50 \mathrm{p}$.

1948, Report of the Commissioner of Mines for the biennium ended December 31, 1948: Juneau, Alaska, 50 p.

1952, Report of the Commissioner of Mines for the biennium ended December 31, 1952: Juneau, Alaska, 66 p.

1955, Report of the Commissioner of Mines for the biennium ended December 31, 1954: Juneau, Alaska, $110 \mathrm{p}$.

1957, Report of the Commissioner of Mines for the biennium ended December 31, 1956: Juneau, Alaska, $103 \mathrm{p}$. 
1958, Report of the Commissioner of Mines for the biennium ended December 31, 1958, $83 \mathrm{p}$.

Alaska Division of Geological and Geophysical Surveys, 1969, Report for the year, 1969: College, Alaska, 68 p.

1972, Annual report 1971: Anchorage, Alaska, 109 p.

1973, Annual report 1972: Anchorage, Alaska, 57 p.

1974a, Brooks Range Project, in Annual Report 1973:

Anchorage, Alaska, p. 6-9.

1974b, Geochronology of southwestern Brooks Range metamorphic rocks, in Annual report 1973: Anchorage, Alaska, p. 27-30.

1974c, Ruby Ridge traverse, southwestern Brooks Brooks Range, in Annual report 1973: Anchorage, Alaska, p. 34-36.

1975, Aeromagnetic map, western two thirds of Ambler River quadrangle, Alaska: Alaska Division of Geological and Geophysical Surveys Open-File Map 76, 3 p., scale $1: 250,000$. $53 \mathrm{p}$.

1976, Biennial report, 1974-1975: College, Alaska,

Alaska Division of Geological Survey, 1970, Report for the year 1970: College, Alaska, 86 p.

1972, Annual Report 1971: Anchorage, Alaska, 109 p.

Alaska Division of Mines and Geology, 1968, Report for the year 1968: College, Alaska, $67 \mathrm{p}$.

1969, Report for the year, 1969: College, Alaska, $68 \mathrm{p}$.

Alaska Division of Mines and Minerals, 1959, Report of the Division of Mines and Minerals for the year 1959: Juneau, Alaska, 80 p. 1960, Report for the year 1960: Juneau, Alaska, 88 p. 1961, Report for the year 1961: Juneau, Alaska, 108 p. 1962, Report for the year 1962: Juneau, Alaska, 119 p. 1963, Report for the year 1963: Juneau, Alaska, 87 p. 1964, Report for the year 1964: Juneau, Alaska, 107 p 1965, Report for the year 1965: Juneau, Alaska, 99 p. 1966, Report for the year 1966: Juneau, Alaska, 115 p. 1967, Report for the year 1967: College, Alaska, 98 p.

Alaska Field Operations Center, 1978, Mineral appraisal of the proposed Kobuk Valley National Park, Alaska: A preliminary comment: Anchorage, U.S. Bureau of Mines Open-File Report 110-78, 31 p.

Albert, N. R. D., 1978, Interpretation of landsat imagery of the Ambler River quadrangle, Alaska: U.S. Geological Survey Open-file Report 78-120-J, scale 1:2,500,000, 2 sheets.

*Albert, N. R. D., and Steele, W. C., 1976a, Interpretation of Landsat imagery of the McCarthy quadrangle, Alaska: U.S. Geological Survey Miscellaneous Field Studies Map MF-773-N, scale 1:250,000, 3 sheets.

*___ 1976b, Interpretation of Landsat imagery of the Tanacross quadrangle, Alaska: U.S. Geological Survey Miscellaneous Field Studies Map MF-767-C, scale 1:250,000, 3 sheets.

Anderson, Eskil, 1945, Asbestos and jade occurrences in the Kobuk River region, Alaska: Alaska Department of Mines Pamphlet 3-R, 26 p.

1947, Mineral occurrences other than gold deposits in northwestern Alaska: Alaska Department of Mines Pamphlet 5-R, 48 p.

Andreasen, G.E., 1960, Total intensity aeromagnetic profiles of Kobuk River, Alaska: U.S. Geological Survey Open-File Report 60-7, 5 sheets.

Bain, H. F., 1946, Alaska's minerals as a basis for industry: U.S. Bureau of Mines Information Circular 7379, 89 p.
Barnes, D. F., 1967, Four preliminary gravity maps of parts of Alaska: U.S. Geological Survey Open-File Report 67-10, 5 p., scale 1:5,000,000.

1976, Bouger gravity maps of Alaska: U.S. Geological Survey Open-File Report 76-70, scale 1:2,500,000, 1 sheet.

Barnes, F. F., 1967, Coal resources of Alaska: U.S. Geological Survey Bulletin 1242-B, p. B1-B36.

Beikman, H. M., and Lathram, E. H., 1976, Preliminary geologic map of northern Alaska: U.S. Geological Survey Miscellaneous Field Studies Map MF-789, scale 1:1,000,000, 2 sheets.

Berg, H. C., and Cobb, E. H., 1967, Metalliferous lode deposits of Alaska: U.S. Geological Survey Bulletin 1246, $254 \mathrm{p}$.

Bottge, R. G., 1974, Potential mineral resources in selected D.2 lands: U.S. Bureau of Mines Open-File Report 9-74, $55 \mathrm{p}$.

1975, Impact of a natural gas pipeline on mineral and energy development in Alaska: U.S. Bureau of Mines Open-File Report 20-75, 177 p.

Brooks, A. H., 1902, The coal resources of Alaska: U.S. Geological Survey 22nd Annual Report pt. 3, p. 515-571.

1904, Placer mining in Alaska in 1903: U.S. Geological Survey Bulletin 225, p. 43-59.

1905, Report on progress of investigations of mineral resources of Alaska in 1904: U.S. Geological Survey Bulletin 259, p. 24-25.

1906, Report on progress of investigations of mineral resources of Alaska in 1905: U.S. Geological Survey Bulle$\operatorname{tin} 284$, p. 8 .

1909, The mining industry in 1908: U.S. Geological Survey Bulletin 379, p. 21-62.

1910, The mining industry in 1909: U.S. Geological Survey Bulletin 442, p. 20-46.

1912, The mining industry in 1911: U.S. Geological Survey Bulletin 520, p. 17-44.

1913, The mining industry in 1912: U.S. Geological Survey Bulletin 542, p. 18-52.

1914, The Alaskan mining industry in 1913: U.S. Geological Survey Bulletin 592, p. 45-74.

1915, The Alaskan mining industry in 1914: U.S. Geological Survey Bulletin 622, p. 15-68.

1916, The Alaska mining industry in 1915: U.S. Geo logical Survey Bulletin 642, p. 16-71.

1921, The future of Alaska mining: U.S. Geological Survey Bulletin 714, p. 5-57.

1922, The Alaska mining industry in 1920: U.S. Geological Survey Bulletin 722, p. 7-67.

1923, The Alaskan mining industry in 1921: U.S. Geological Survey Bulletin 739, p. 1-44.

1925, Alaska's mineral resources and production, 1923: U.S. Geological Survey Bulletin 773, p. 3-52.

Brooks, A. H., and Capps, S. R., 1924, The Alaskan mining industry in 1922: U.S. Geological Survey Bulletin 755, p. 3-49.

Brooks, A. H., and Martin, G. C., 1921, The Alaskan mining industry in 1919: U.S. Geological Survey Bulletin 714, p. 59-95.

Brosgé, W. P., Reiser, H. N., and Tailleur, I. L., 1967, Copper analyses of selected samples, southwestern Brooks Range, Alaska: U.S. Geological Survey Open-File Report 67-29, 1 sheet.

Callahan, W. H., 1977, Some thoughts regarding premises 
and procedures for prospecting for base metal ores in carbonate rocks in the North American Cordillera: Economic Geology, v. 72, p. 71-81.

Cantwell, J. C., 1887, Map of Kowak (Kobuk) River, Alaska, in Healy, M. A., Report of the cruise of the Revenue Marine Steamer Corwin in the Arctic Ocean in the year 1885: Washington, D. C., Government Printing Office, $102 \mathrm{p}$.

1889, A narrative account of the exploration of the Kowak (Kobuk) River, Alaska, in Healy, M. A., Report of the cruise of the Revenue Marine Steamer Corwin in the Arctic Ocean in the year 1884: Washington, D.C., Government Printing Office, p. 47-74.

Carden, J. R., 1978, The comparative petrology of blueschists and greenschists in the Brooks Range and KodiakSeldovia schist belts: Fairbanks, Alaska, University of Alaska, Ph.D. thesis, 242 p.

Cathcart, S. H., 1920, Mining in northwestern Alaska, in Martin, G. C., and others, Mineral Resources of Alaska ... in 1918: U.S. Geological Survey Bulletin 712, p. 197198.

Churkin, Michael, Jr., 1973, Paleozoic and Precambrian rocks of Alaska and their role in its structural evolution: U.S. Geological Survey Professional Paper 740,64 p.

Clarke, F. W., and Merrill, G. P., 1888, On nephrite and jadeite: U.S. National Museum Proceedings, v. 11, p. 115-130.

Coats, R. R., 1944, Asbestos deposits of the Dahl Creek area, Kobuk River district, Alaska: U.S. Geological Survey Open-File Report 44-27, 4 p.

Cobb, E. H., 1972, Metallic mineral resources map of the Ambler River quadrangle, Alaska: U.S. Geological Survey Miscellaneous Field Studies Map MF-454, scale 1:250,000, 1 sheet.

1973, Placer deposits of Alaska: U.S. Geological Survey Bulletin 1374, $213 \mathrm{p}$.

1975, Summary of references to mineral occurrences (other than mineral fuels and construction materials) in northern Alaska: U.S. Geological Survey Open-File Report 75-628, $106 \mathrm{p}$.

1977, Placer deposits map of central Alaska: U.S. Geological Survey Open-File Report 77-168B, 64 p. scale 1:1,000,000.

Cobb, E. H., and Mayfield, C. F., 1981a, Summaries of data on and lists of references to metallic and selected nonmetallic mineral occurrences in the Ambler River quadrangle, Alaska, Supplement to Open-File Report 75-628; Part A Summaries of data to January 1, 1981: U.S. Geological Survey Open-File Report 81-570A, p. A1-A13.

$1981 \mathrm{~b}$, Summaries of data on and lists of references to metallic and selected nonmetallic mineral occurrences in the Ambler River quadrangle, Alaska; Supplement to Open-File Report 75-628; Part B - Lists of references to January 1, 1981: U.S. Geological Survey Open-File Report 81-570B, p. B1-B11.

*Condit, C. D., and Chavez, P. S., Jr., 1978, Basic concepts of computerized digital image processing for geologists: U.S. Geological Survey Bulletin 1462, 16 p.

*Cox, D. P., Schmidt, R. G., Vine, J. D., Kirkemo, Harold, Tourtelot, E. B., and Fleischer, Michael, 1973, Copper, in Brobst, D. A., and Pratt, W. P., eds., United States Mineral Resources: U.S. Geological Survey Professional Paper 820 , p. $163-190$.
Dake, H. C., 1945, Alaska jade deposits: Mineralogist, v. 13, no. 9, p. 328-329.

Dall, W. H., 1896, Report of coal and lignite of Alaska: U.S. Geological Survey 17th Annual Report, pt. 1, p. 763-908.

Dall, W. H., and Harris, G. D., 1892, Correlation papers: Neocene: U.S. Geological Survey Bulletin 84, 349 p.

Dempsey, W. J., Meuschke, J. L., and Andreasen, G. E., 1957, Total intensity aeromagnetic profiles of West Hogatza, Alaska: U.S. Geological Survey Open-File Report 57-36, scale $1: 25,000,1$ sheet.

Dillon, J. T., and Gilbert, W. G., 1978, U-Pb zircon age dates shed new light on Brooks Range deposits: Alaska Division of Geological and Geophysical Surveys, Mines and Geology Bulletin, v. 27, p. 16.

Dillon, J. T., and Pessel, G. H., 1979, Tectonic significance of late Devonian and late proterozoic $\mathrm{U} / \mathrm{Pb}$ zircon ages from metaigneous rocks, Brooks Range, Alaska, (abs.): in Geological Society of America Abstracts with Programs, Cordillera Section, 75th Annual Meeting, San Jose, Calif., Apr. 9-11, p. 75.

Dillon, J. T., Pessel, G. H., Chen, J. H., and Veach, N. C., 1979, Tectonic and economic significance of late Devonian and late Proterozoic U-Pb zircon ages from the Brooks Range, Alaska: Alaska Division of Geological and Geophysical Surveys, Short Notes on Alaskan Geology, Geologic Report 61, p. 36-41.

1980, Middle Paleozoic magmatism and orogenesis in the Brooks Range, Alaska: Geology, v. 8, p. 338-343.

*Donovan, T. J., and Tailleur, I. L., 1975, Map showing paleocurrent and clast-size data from the Devonian-Mississippian Endicott Group, northern Alaska: U.S. Geological Survey Miscellaneous Field Studies Map 692, scale 1:2,000,000, 1 sheet.

*Dutro, J. T., Brosgé, W. P., Lanphere, M. A., and Reiser, H. N., 1976, Geologic significance of Doonerak structural high, central Brooks Range, Alaska: American Association of Petroleum Geologists Bulletin, v. 60, p. 952-961.

Eakins, G. R., 1968, Uranium in Alaska (abs.), in Alaska Division of Mines and Geology, Report for the year 1968: College, Alaska, p. 23.

Ellersieck, Inyo, 1978a, Analytical results for streamsediment geochemical samples, Ambler River quadrangle, Alaska: U.S. Geological Survey Open-File Report 78-120C, scale $1: 250,000,6$ sheets.

1978b, Map showing barium, silver, and arsenic stream-sediment geochemical anomalies, Ambler River quadrangle, Alaska: U.S. Geological Survey Open-file Report 78-120-G, scale 1:250,000, 1 sheet.

1978c, Map showing chromium, nickel, and cobalt stream-sediment geochemical anomalies, Ambler River quadrangle, Alaska: U.S. Geological Survey Open-File Report 78-120-H, scale 1:250,000, 1 sheet.

1978d, Map showing copper and molybdenum streamsediment geochemical anomalies, Ambler River quadrangle, Alaska: U.S. Geological Survey Open-File Report 78120-E, scale 1:250,000, 1 sheet.

1978e, Map showing lead and zinc stream-sediment geochemical anomalies, Ambler River quadrangle, Alaska: U.S. Geological Survey Open-File Report 78-120-D, scale 1:250,000, 1 sheet.

1978f, Map showing stream-sediment geochemical sample locations, Ambler River quadrangle, Alaska: U.S. 
Geological Survey Open-File Report 78-120-B, scale $1: 250,000,1$ sheet.

1978g, Map showing tin and beryllium streamsediment geochemical anomalies, Ambler River quadrangle, Alaska: U.S. Geological Survey Open-File Report 78-120-F, scale 1:250,000, 1 sheet.

*Ellersieck, Inyo, Mayfield, C. F., Tailleur, I. L., and Curtis, S. M., 1979, Thrust sequences in the Misheguk Mountain quadrangle, Brooks Range, Alaska, in Johnson, K. M., and Williams, J. R., eds., The United States Geological Survey in Alaska-Accomplishments during 1979: U.S. Geological Survey Circular 804-B, p. B8.

Fackler, W. C., 1945, Occurrence of nemalite in Alaska: American Mineralogist, v. 30, p. 640-641.

Fernald, A. T., 1964, Surficial geology of the central Kobuk River valley, northwestern Alaska: U.S. Geological Survey Bulletin 1181-K, p. K1-K31.

Fernald, A. T., and Nichols, D. R., 1953, Active sand dunes in the Kobuk River valley, northwestern Alaska (abs.): Geological Society of America Bulletin, v. 64, p. 14211422.

Forbes, R. B., Carden, J. R., Turner, D. L., and Connelly, W. 1979, Regional tectonic implications of Alaskan blueschist terranes, in Sisson, Alexander, ed., The relationship of plate tectonics to Alaskan geology and resources: Alaska Geological Society Symposium, Anchorage, 1977, Proceedings: p. L1-L28.

Forbes, R. B., Hamilton, Thomas, Tailleur, I. L., Miller, T. P., and Patton, W. W., Jr., 1971, Tectonic implications of blueschist facies metamorphic terranes in Alaska: Nature Physical Science, v. 234, p. 106-108.

Forbes, R. B., Turner, D. L., Gilbert, W. G., and Carden, J. R., 1974, Ruby Ridge traverse, southwestern Brooks Range: Alaska Division Geological and Geophysical Surveys 1973 Annual Report, p. 34-36.

Fritts, C. E., 1969a, Geology and geochemistry in the southeastern part of the Cosmos Hills, Shungnak D-2 quadrangle, Alaska: Alaska Division of Mines and Geology Geologic Report 37, 35 p.

1969b, Geology and geochemistry of the Cosmos Hills, western Arctic Alaska (abs.), in Alaska Division of Mines and Geology, Report for the year 1969: College, Alaska, p. 8-9.

1970, Geology and geochemistry of the Cosmos Hills, Ambler River and Shungnak quadrangles, Alaska: Alaska Division of Mines and Geology Geologic Report $39,69 \mathrm{p}$.

Garland, R. E., and Pessel, G. H., 1975, Geochemical analysis of stream-sediment samples from the Ambler River A1-A3, B1-B3, and C1-C3 quadrangles, Alaska: Alaska Division of Geological and Geophysical Surveys OpenFile Report 37, scale 1:63,360.

Garland, R. E., Pessel, G. H., Trible, T. C., and McClintock, W. W., 1975, Geochemical analyses of stream-sediment and soil samples from Ambler River A-4, A-5, B-4, B-5, and C-5 quadrangles, Alaska: Alaska Division of Geologic and Geophysical Surveys Open-File Report 38, 2 p.

Gealey, W. K., 1980, Ophiolite obduction mechanism, Cyprus Geological Survey Department: In Panayiotou, A., ed., Ophiolites: Proceedings International Ophiolite Symposium, Nicosia, Cyprus, 1979, p. 228-243.

Gilbert, W. G., Wiltse, M. A., Hackett, S. W., Carden, J. R., and Forbes, R. B., 1977, Geology of Ruby Ridge, southwestern Brooks Range: Alaska Division of Geological and Geophysical Surveys Geologic Report 58, 16 p.

Gilbert, W. G., Wiltse, M. A., Henning, M. W. Buza, J. W., and Kline, J. T., 1975, Structural geology of Ruby Ridge, Ambler River A-2, B-2 quadrangles, Alaska: Alaska Division of Geological and Geophysical Surveys, Mines and Geology Bulletin, v. 24, no. 24, p. 2.

Grantz, Arthur, 1966, Strike-slip faults in Alaska: U.S. Geological Survey Open-File Report 66-53, p. 82.

Grinnell, Elizabeth, 1901, Gold hunting in Alaska as told by Joseph Grinnell: Chicago, David C. Cook Publishing Company, $96 \mathrm{p}$.

Grybeck, Donald, 1977a, Known mineral deposits of the Brooks Range, Alaska: U.S. Geological Survey Open-File Report 77-166-C, 45 p.

$1977 \mathrm{~b}$, Map showing geochemical anomalies in the Brooks Range, Alaska: U.S. Geological Survey Open-File Report 77-166-D, scale 1:1,000,000, 1 sheet.

Grybeck, Donald, Beikman, H. M., Brosgé, W. P., Tailleur, I. L., and Mull, C. G., 1977, Geologic map of the Brooks Range, Alaska: U.S. Geological Survey Open-File Report 77-166B, scale 1:1,000,000.

Hackett, S. W., 1975, Regional gravity surveys: Alaska Division of Geological and Geophysical Surveys, Mines and Geology Bulletin, v. 24, p. 1-2.

1977, Aeromagnetic map of southwestern Brooks Range, Alaska: Alaska Division of Geological and Geophysical Surveys Geologic Report 56, scale 1:250,000, 2 sheets.

1980, Aeromagnetic interpretation maps of the Ambler River quadrangle, Alaska: U.S. Geological Survey Open-File Report 78-120-K, 19 p., scale 1:250,000, 3 sheets.

Hawley, C. C., 1976, Exploration and distribution of stratiform sulfide deposits in Alaska: Alaska Geological Society Symposium Proceedings on Recent and Ancient Sedimentary Environments in Alaska, Anchorage, Alaska, $1975,23 \mathrm{p}$.

Heide, H. E., Wright, W. S., and Rutledge, F. A., 1949, Investigations of the Kobuk River asbestos deposits, Kobuk district, northwestern Alaska: U.S. Bureau of Mines Report of Investigations 4414, 25 p.

Hershey, O. H., 1909, The ancient Kobuk glacier of Alaska: Journal of Geology, v. 17, p. 83-91.

Hitzman, M. W., 1978, Geology of the BT Claim Group, southwestern Brooks Range, Alaska: Seattle, Wash., Seattle University, Masters thesis, $80 \mathrm{p}$.

1980 , Devonian to recent tectonics of the southwestern Brooks Ranges, Alaska (abs.): Geological Society of America, 93rd annual meeting, Atlanta, GA., 1980, Abstracts with Programs, p. 447.

1981a, Cosmos Hills (abs.): Alaska Mines and Geology, v. 30 , no. 1, p. 5 .

$1981 \mathrm{~b}$, Geology of the BT Claim Group, southwestern Brooks Range, Alaska, in Silberman, M. L., Field, C. W., and Berry, A. L., eds., Proceedings of the Symposium on Mineral Deposits of the Pacific Northwest: U.S. Geological Survey Open-File Report 81-355, p. 17-28.

Hitzman, M. W., Smith, T. E., and Proffett, J. M., 1982, Bedrock geology of the Ambler District, southwestern Brooks Range, Alaska: Alaska Division of Geological and 
Geophysical Surveys Geologic Report 75, scale 1:125,000, 2 sheets.

Hollick, Arthur, 1936, The Tertiary floras of Alaska, with a chapter on the geology of the Tertiary deposits, by P. S. Smith: U.S. Geological Survey Professional Paper 182, $185 \mathrm{p}$.

Jansons, Uldis, and Bottgé, R. G., 1977, Economic mining feasibility studies of selected mineral deposit types in the western Brooks Range, Alaska: U.S. Bureau of Mines Open-File Report 128-77, 96 p.

Joesting, H. R., 1942, Strategic mineral occurrences in interior Alaska: Alaska Department of Mines Pamphlet 1, $46 \mathrm{p}$.

Kelsey, G. L., 1979, Felsic volcanics of the Brooks Range schist belt: Tempe, Ariz., Arizona State University, Masters thesis, $124 \mathrm{p}$.

Kelsey, G. L., Glavinovich, P. S., and Sheridan, M. F., 1980, High-potassium metarhyolites associated with volcanogenic sulfides, Ambler district, northwest Alaska, (abs.): Geological Society of America Abstracts with Programs, v. 12, no. 3, p. 114.

Kline, J. T., 1976, Lode claim groups of the southwestern Brooks Range copper belt, Ambler River and Survey Pass quadrangles, Alaska (filed prior to January, 1976): Alaska Division of Geological and Geophysical Surveys Open-File Report 99, 1 p., scale 1:63,360, 3 sheets.

Knox, R. C., 1968, $\$ 10$ million gamble at Bornite could pay big dividends: Alaska Construction and Oil, v. 9, no. 2, p. $16-21$.

LeCompte, J. R., and Steele, W. C., 1981, Landsat data interpretation in the south-central Brooks Range and in southeastern Alaska, in Albert, N. R. D., and Hudson, Travis, eds., The United States Geological Survey in Alaska: Accomplishments during 1979: U.S. Geological Survey Circular 823-B, p. B1-B3.

Leiper, H. N., ed., 1969, Bill Munz lives as many would like to: Lapidary Journal, Buyer's Guide issue, April, p. 50-54.

Lund, R. J., 1961, Future of Alaskan mineral industry: Mining Engineering, v. 13, p. 1351-1355.

*Martin, A. J., 1970, Structure and tectonic history of the western Brooks Range DeLong Mountains and Lisburne Hills, northern Alaska: Geological Society of America Bulletin, v. 81, p. 3605-3622.

Martin, G. C., 1919, The Alaskan mining industry in 1917: U.S. Geological Survey Bulletin 692, p. 11-42.

1920, The Alaskan mining industry in 1918: U.S. Geological Survey Bulletin 712, p. 11-52.

Matzko, J. J., and Freeman, V. L., 1963, Summary of reconnaissance for uranium in Alaska, 1955: U.S. Geological Survey Bulletin 1155, p. 33-49.

Mayfield, C. F., 1976, Metamorphism in the southwestern Brooks Range, in Cobb, E. H., ed., The United States Geological Survey in Alaska-Accomplishments during 1975: U.S. Geological Survey Circular 733, p. 31-32.

Mayfield, C. F., and Grybeck, Donald, 1978, Mineral occurrences and resources map of the Ambler River quadrangle, Alaska: U.S. Geological Survey Open-File Report 78120-I, scale $1: 250,000,1$ sheet.

*Mayfield, C. F., Tailleur, I. L., Mull, C. G., and Sable, E. G., 1978, Bedrock geologic map of the south half of National Petroleum Reserve in Alaska: U.S. Geological Survey Open-File Report 78-70-B, scale 1:500,000, 2 sheets.

Mayfield, C. F., and Tailleur, I. L., 1978, Bedrock geology map of the Ambler River quadrangle, Alaska: U.S. Geological Survey Open-File Report 78-120-A, scale 1:250,000, 1 sheet.

McLenegan, S. B., 1887, Exploration of the Noatak River, Alaska, in Healey, M. A., Report of the cruise of the Revenue Marine Steamer Corwin in the Arctic Ocean in the year 1885: Washington, D.C., Government Printing Office, p. $55-80$.

1889, Exploration of the Kowak River, Alaska-Notes on the natural history and resources, in Healy, M. A., Report of the Cruise of the Revenue Marine Steamer Cor win in the Arctic Ocean in the year 1884: Washington, U.S. Treasury Department, 99-108.

Mendenhall, W. C., 1902, Reconnaissance from Fort Hamlin to Kotzebue Sound, Alaska, by way of Dall, Kanuti, Allen, and Kowak Rivers: U.S. Geological Survey Professional Paper 10,68 p.

Moffit, F. H., 1927, Mineral industry in Alaska in 1925: U.S. Geological Survey Bulletin 792, p. 1-39.

Mull, C. G., Tailleur, I. L., Mayfield, C. F., and Pessel, G. H., 1976, New structural and stratigraphic interpretations, central and western Brooks Range and Arctic Slope, in Cobb, E. H., ed., The United States Geological Survey in Alaska-Accomplishments during 1975: U.S. Geological Survey Circular 733, p. 24-26.

Mull, C. G., and Tailleur, I. L., 1977, Sadlerochit(?) Group in the Schwatka Mountains, south-central Brooks Range, in Blean, K. M., ed., The United States Geological Survey in Alaska-Accomplishments during 1976: U.S. Geological Survey Circular 751-B, p. 27.

Nelsen, C. J., 1979, The geology and blueschist petrology of the western Ambler schist belt, southwestern Brooks Range, Alaska: Albuquerque, N. Mex., University of New Mexico, Masters thesis, $123 \mathrm{p}$.

Nelson, S. W., Grybeck, Donald, and Silberman, M. L., 1979, Cataclastic granitic rocks in the central Brooks Range, Alaska, (abs.): in Geological Society of America Abstracts with Programs, Cordillera Section, 75th Annual Meeting, San Jose, CA., April 9-11, p. 119.

Nilsen, T. H., Moore, T. E., Dutro, J. T., Jr., Brosgé, W. P., and Orchard, D. M., 1980, Sedimentology and stratigraphy of the Kanayut Conglomerate and associated units, central and eastern Brooks Range, Alaska-Report of 1978 field season: U.S. Geological Survey Open-File Report 80-888, $40 \mathrm{p}$.

Oliver, W. A., Jr., Merriam, C. W., and Churkin, Michael, Jr., 1975, Ordovician, Silurian, and Devonian corals of Alaska: U.S. Geological Survey Professional Paper 823-B, p. $13-44$.

Overstreet, W. C., Hamilton, J. C., Boerngen, J. G., Rosemblum, Sam, Marsh, W. R., and Sainsbury, C. L., 1975, Minor elements in nonmagnetic concentrates from Alaska: National Technical Information Service PB-238 989/AS, $440 \mathrm{p}$.

Patton, W. W., Jr., 1973, Reconnaissance geology of the northern Yukon-Koyukuk province, Alaska: U.S. Geological Survey Professional Paper 774-A, p. A1-A17.

Patton, W. W., Jr., Miller, T. P., and Tailleur, I. L., 1968, Regional geologic map of the Shungnak and southern part of the Ambler River quadrangles, Alaska: U.S. Geological Survey Miscellaneous Geologic Investigations Map I-554, scale $1: 250,000,1$ sheet.

Patton, W. W., Tailleur, I. L., Brosgé, W. P., and Lanphere, 
M. A., 1978, Preliminary report on the ophiolites of northern and western Alaska, in Coleman, R. G. and Irwin, W. P., eds., North American Ophiolites: Oregon Department of Geology and Mineral Industries Bulletin 95, p. 51-57.

Pessel, G. H., 1976, Geochemistry of stream-sediment samples in southwestern Ambler River quadrangle, Alaska: Alaska Division of Geological and Geophysical Surveys Open-File Report 71, 2 p., scale 1:200,000, 3 sheets.

1977, Probable karst topography near Jade Mountains, southwestern Brooks Range, Alaska: Alaska Division of Geological and Geophysical Surveys Geologic Report 55, p. 3-5.

Pessel, G. H., and Brosgé, W. P., 1977, Preliminary reconnaissance geologic map of Ambler River quadrangle: U.S. Geological Survey Open-File Report 77-28, scale $1: 250,000,1$ sheet.

Pessel, G. H., Garland, R. E., Tailleur, I. L., and Eakins, G. R., 1973, Preliminary geologic map of southeastern Ambler River and southwestern Survey Pass quadrangles, Alaska: Alaska Division of Geological and Geophysical Surveys Open-File Report 36, scale 1:63,360, 2 sheets.

Petroleum Information, 1978, Ambler mining reports second significant mining discovery in Brooks Range: Anchorage, Alaska, v. 24, no. 17, sec. 1, p. 2.

Péwé, T. L., 1975, Quaternary geology of Alaska: U.S. Geological Survey Professional Paper 835, 145 p.

Péwé, T. L., Muller, N. E., Karlstrom, Thor, N. V., Krinsley, D. B., Fernald, A. T., Wahrhaftig, Clyde, Hopkins, D. M., and Detterman, R. L., 1953, Multiple glaciation in Alaska, a progress report: U.S. Geological Survey Circular 289, $13 \mathrm{p}$.

Plafker, George, Hudson Travis, and Jones, D. L., 1978, Upper Triassic radiolarian chert from the Kobuk volcanic sequence in the southern Brooks Range, in Johnson, K. M., ed, The United States Geological Survey in Alaska-Accomplishments during 1977: U.S. Geological Survey Circular 772-B, p. B45-B47.

Read, W. F., and Lehner, R. E., 1959, Geology of the Cosmos Hills, Alaska: Bear Creek Mining Company, unpublished report, $63 \mathrm{p}$.

Reed, Irving, 1931, Report on the placer deposits of the upper Kobuk goldfields: Alaska Department of Mines unpublished report, $33 \mathrm{p}$.

Roeder, Dietrick, and Mull, C. G., 1978, Tectonics of Brooks Range ophiolites, Alaska: American Association of Petroleum Geologists Bulletin, v. 62, p. 1696-1702.

Runnells, D. D., 1963, The copper deposits of Ruby Creek, Cosmos Hills Alaska: Cambridge, Mass., Harvard University, Ph.D. dissertation, 274 p.; 1964, University Microfilms, Ann Arbor, Michigan.

1964, Cymrite in a copper deposit, Brooks Range, Alaska: America Mineralogist, v. 49, nos. 1-2, p. 158-165.

1965, Anthraxolite derived from indigenous organic matter in Middle Devonian dolomite, Cosmos Hills; Alaska: Journal of Sedimentary Petrology, v. 35, no. 3, p. 599-603.

1966, Mineralization of the Ruby Creek (Bornite) copper deposit, Cosmos Hills, Alaska: Economic Geology, v. 61 , no. 7 , p. 1305 .

1969, The mineralogy and sulfur isotopes of the Ruby Creek copper prospect, Bornite, Alaska: Economic Geology, v. 64 , no. 1, p. $75-90$.

Russell, I. C., 1890, Ice cliffs on Kowak River, Alaska, ob- served by Lieut. Cantwell: American Geologist, v. 6, p. $49-52$.

Saunders, R. H., 1953, Report on the preliminary examination of the Berg prospect Ruby Creek, Shungnak district, Alaska: Alaska Territory Department of Mines unpublished property-examination report PE 28-1, February, $10 \mathrm{p}$.

1955, Report on the examination of the Kobuk copper prospect, Shungnak district, Alaska: Alaska Territory Department of Mines unpublished propertyexamination report PE 28-2, October, 9 p.

1956, Supplementary report on the Kobuk copper prospect, Shungnak district, Alaska: Alaska Territory Department of Mines unpublished property-examination report PE 28-3, December, 3 p.

1963, Report on explortaion at Ruby Creek, Kobuk district Alaska: Alaska Division of Mines and Minerals unpublished property-examination report PE 28-4, March, 3 p.

Schmidt, J. M., 1981, Volcanogenic massive sulfide depositions in a rifted continental margin: The Arctic Camp deposit, southwestern Brooks Range, Alaska, (abs.): Geological Society of America Abstracts with Programs, v. 13, no. 7 , p. 548 .

*Shride, A. F., 1973, Asbestos, in Brobst, D. A., and Pratt, W. P., eds., United States mineral resources: U.S. Geological Survey Professional Paper 820, p. 63-73.

Sichermann, H. A., Russell, R. H., and Fikkan, P. R., 1976, The geology and mineralization of the Ambler district, Alaska: unpublished address to the Pacific Northwest Metals and Minerals conference, American Institute of Mining Engineers, Coeur d'Alene, Idaho, Apr. 9, 22 p.

Smith, P. S., 1912, The Alatna-Noatak region: U.S. Geological Survey Bulletin 520, p. 315-338.

1913, The Noatak-Kobuk region, Alaska: U.S. Geological Survey Bulletin 536, 160 p.

1926, Mineral industry of Alaska in 1924: U.S. Geological Survey Bulletin 783, p. 1-30.

1929, Mineral industry of Alaska in 1926: U.S. Geolog-

ical Survey Bulletin 797, p. 1-50.

1930a, Mineral industry of Alaska in 1927: U.S. Geo-

logical Survey Bulletin 810, p. 1-64.

$1930 \mathrm{~b}$, Mineral industry of Alaska in 1928: U.S. Geo-

logical Survey Bulletin, 813, p. 1-72.

1932, Mineral industry of Alaska in 1929: U.S. Geolog-

ical Survey Bulletin, 824, p. 1-81.

1933a, Mineral industry of Alaska in 1930: U.S. Geo-

logical Survey Bulletin 836, p. 1-83.

$1933 \mathrm{~b}$, Mineral industry of Alaska in 1931: U.S. Geo-

logical Survey Bulletin 844-A, p. 1-82.

1934a, Mineral industry of Alaska in 1932: U.S. Geo-

logical Survey Bulletin 857-A, p. 1-91.

1934b, Mineral industry of Alaska in 1933: U.S. Geo-

logical Survey Bulletin 864-A, p. 1-94.

1936, Mineral industry of Alaska in 1934: U.S. Geo-

logical Survey Bulletin 868-A, p. 1-91.

1937, Mineral industry of Alaska in 1935: U.S. Geolog-

ical Survey Bulletin 880-A, p. 1-95.

1938, Mineral industry of Alaska in 1936: U.S. Geolog-

ical Survey Bulletin 897-A, p. 1-107.

1939a, Areal geology of Alaska: U.S. Geological Sur-

vey Professional Paper 192, 100 p. 
1939b, Mineral industry of Alaska in 1937: U.S. Geo-

logical Survey Bulletin 910-A, p. 1-113.

1939c, Mineral industry of Alaska in 1938: U.S. Geo-

logical Survey Bulletin 917-A, p. 1-113.

1941a, Fineness of gold from Alaska placers: U.S. Geo-

logical Survey Bulletin 910-C, p. C147-C272.

1941b, Mineral industry of Alaska in 1939: U.S. Geo-

logical Survey Bulletin 926-A, p. A1-A106.

1942, Mineral industry of Alaska in 1940: U.S. Geolog-

ical Survey Bulletin 933-A, p. A1-A102.

Smith, P. S., and Eakin, H. M., 1911, The Shungnak region, Kobuk Valley: U.S. Geological Survey Bulletin 480, p. 271-305.

Smith, P. S., and Mertie, J. B., Jr., 1930, Geology and mineral resources of northwestern Alaska: U.S. Geological Survey Bulletin 815, 351 p.

Smith, P. S., Mertie, J. B., Jr., and Foran, W. T., 1926, Summary of recent surveys in northern Alaska: U.S. Geological Survey Bulletin 783, p. 151-168.

Smith, T. E., Proffett, J. M., Heatwole, D. A., and Seklemian, R., 1977, Geologic setting of base-metal massive sulfide deposits, Ambler District, northwest Alaska (abs.): The relationship of plate tectonics to Alaskan Geology and re sources: Alaskan Geological Society Symposium, Anchorage, Alaska, 1977, Program and Abstracts, p. 41-42.

Smith, T. E., Webster, G. D., Heatwole, D. A., Proffett, J. M., Kelsey, G., and Glavinovich, P. S., 1978, Evidence for midPaleozoic depositional age of volcanogenic base metal massive sulfide occurrences and enclosing strata, Ambler District, Northwest Alaska (abs.): Geologic Society of America Abstracts with Programs, v. 10, no. 3, p. 148.

Staff, Alaska Field Operations Center, 1979, A mineral appraisal of the areas traversed by the Kobuk, Killick, Alatna and John Rivers, and the North Fork of the Koyukuk River, Brooks Range, Alaska-A summary report: U.S. Bureau of Mines Open-File Report 36-79, 23 p.

1979, A mineral appraisal of the areas traversed by the Salmon and Noatak Rivers in the western Brooks RangeA summary report: U.S. Bureau of Mines Open-File Report 50-79, 16 p.

Steele, W. C., LeCompte, J. R., and Albert, N. R. D., 1979, Landsat data interpretation for various AMRAP quadrangles, Alaska, in Johnson, K. M., and Williams, J. R., eds., The United States Geological Survey in AlaskaAccomplishments during 1978: U.S. Geological Survey Circular 804-B, p. B3-B4.

Stewart, B. D., 1931, Report on cooperation between the Territory of Alaska and the United States in making mining investigations and in the inspection of mines for the biennium ending March 31, 1931: Juneau, Alaska, 145 p.

1933, Mining investigations and mine inspection in Alaska, including assistance to prospectors, biennium ending March 31, 1933: Juneau, Alaska, 192 p.

Stoney, G. M., 1900, Naval explorations in Alaska: Annapolis, Md., United States Naval Institute, 105 p.

*Thaden, R. E., 1973, Gem stones, in Brobst, D. A., and Pratt, W. P., eds. United States mineral resources: U.S. Geological Survey Professional Paper 820, p. 247-250.

*Tailleur, I. L., 1973, Probable rift origin of Canada Basin, Arctic Ocean, in Arctic geology: American Association of Petroleum Geologists Memoir 19, p. 526-535.

*Tailleur, I. L. and Brosgé, W. P., 1970, Tectonic history of northern Alaska, in Adkison, W. L., and Brosgé, M. M., eds., Proceedings of the geologic seminar on the North Slope of Alaska: American Association of Petroleum Geologists, Pacific Section, Los Angeles, Calif., 1970, p. E1-E19.

*Tailleur, I. L., Brosgé, W. P., and Reiser, H. N., 1967, Palinspastic analysis of Devonian rocks in northwestern Alaska, International Symposium on the Devonian System, Calgary, 1967, Proceedings Alberta Society of Petroleum Geologists, v. 2, p. 1345-1361.

Tailleur, I. L., Ellersieck, I. F., and Mayfield, C. F., 1977a, Mineral resources of the western Brooks Range, in Blean, K. M., ed., United States Geological Survey in AlaskaAccomplishments during 1976: U.S. Geological Survey Circular 751-B, p. 24.

1977b, Southwestern Brooks Range-Ambler River quadrangle AMRAP, in Blean, K. M., ed., The United States Geological Survey in Alaska-Accomplishments during 1976: U.S. Geological Survey Circular 751-B, p. 22-24.

Tailleur, I. L., Mayfield, C. F., and Ellersieck, I. F., 1977, Late Paleozoic sedimentary sequence, southwestern Brooks Range, in Blean, K. M. ed., The States Geological Survey in Alaska-Accomplishments during 1976: U.S. Geological Survey Circular 751-B, p. 25.

Tailleur, I. L., Pessel, G. H., Brosgé, W. P., and Mayfield, C. F., 1976, Informal cooperation between USGS and State of Alaska Division of Geological and Geophysical Survey in Brooks Range, in Cobb, E. H., ed., The United States Geological Survey in Alaska-Accomplishments during 1975: U.S. Geological Survey Circular 733, p. 27-29.

*Tailleur, I. L., and Snelson, Sigmund, 1969, Large scale thrusting in northwestern Alaska possibly related to rifting of the Arctic Ocean: Geological Society of America Special Paper 121, p. 569.

Turner, D. L., 1974, Geochronology of southwestern Brooks Range metamorphic rocks: Alaska Division of Geological and Geophysical Surveys 1973 Annual Report, p. 27-30.

Turner, D. L., Forbes, R. B., Dillon, J. T., 1979a, K-Ar geochronology of the southwestern Brooks Range, Alaska: Canadian Journal of Earth Sciences Bulletin, v. 16, p. $1789-1804$.

$1979 \mathrm{~b}$, Summary and tectonic implications of radiometric dating in the southern Brooks Range, in Sisson, Alexander, ed., The relationship of plate tectonics to Alaskan geology and resources: Alaska Geological Society Symposium, Anchorage, Alaska, 1977, p. D1-D14.

Turner, D. L., Forbes, R. B., and Mayfield, C. F., 1978, K-Ar geochronology of the Survey Pass, Ambler River, and eastern Baird Mountains quadrangles, southwestern Brooks Range, Alaska: U.S. Geological Survey Open-File Report 78-254, $41 \mathrm{p}$.

*Turner, F. J., 1968, Metamorphic petrology-Mineralogical and field aspects: San Francisco, McGraw-Hill, 403 p.

U.S. Bureau of Mines, 1944, Dahl Creek asbestos deposits, Kobuk River region, Alaska: U.S. Bureau of Mines War Minerals Report 229,6 p.

U.S. Department of the Interior, 1973a, Proposed Noatak National Ecological Range, Alaska, Draft Environmental Impact Statement, 345 p.

1973b, Proposed Kobuk National Monument, Alaska, Draft Environmental Impact Statement, 352 p.

U.S. Geological Survey, 1975a, Metamorphism in the southwestern Brooks Range, in Geological Survey Research 
1975: U.S. Geological Survey Professional Paper 975, p. 64-65.

U.S. Geological Survey, 1975b, New graptolite discovery indicates Lower Ordovician rocks in southwestern Brooks Range, in Geological Survey Research 1975: U.S. Geological Survey Professional Paper 975, p. 64.

Wedow, Helmuth, Jr., White, M. G., and Moxham, R. M., 1952 , Interim report on an appraisal of the uranium possibilities of Alaska: U.S. Geological Survey Open-File Report $52-165,123$ p.

WGM, Inc., 1978, Mineral studies of the western Brooks Range performed under contact JO155089: U.S. Bureau of Mines Open-File Report 103-78, 546 p.

White, M. G., 1950, Examination for radioactivity in a copper-lode on Ruby Creek, Kobuk River valley, Alaska: U.S. Geological and Survey Trace Elements Inventory Report 76-A.

Wilson, F. H., and Turner, D. L., 1975, Radiometric age map of Alaska-northern Alaska: Alaska Division of Geological and Geophysical Surveys Open-File Report 86, 11 p.
Wiltse, M. A., 1975, Geology of the Arctic Camp prospect, Ambler River quadrangle, Alaska: Alaska Division of Geological and Geophysical Surveys Open-File Report 60, 41 p.

Wiltse, M. A., and Gilbert, W. G., 1977, Regional setting of southern Brooks Range copper deposits, Alaska (abs.): Geological Association of Canada Annual Meeting, 1977, Vancouver, B.C., Programs with abstracts, v. 2, p. 55.

Wiltse, M. A., Marsh, S. P., Henning, M. W., and Buza, J. W., 1975, Brooks Range copper belt, southern Ambler River and Survey Pass quadrangles: Alaska Division of Geological and Geophysical Survey, Mines and Geology Bulletin, v. 24, no. 5, p. 2-3.

Wimmler, N. L., 1924, Placer mining in Alaska in 1923, in Stewart, B. D., Annual Report of the Mine Inspector to the Governor of Alaska, 1923: Juneau, Alaska, p. 14-54.

*Winkler, H. G. F., 1979, Petrogenesis of metamorphic rocks: New York, Springer-Verlag, 348 p.

Yount, M. E., ed., 1975, The United States Geological Survey Alaska program, 1975: U.S. Geological Survey Circular $722,58 \mathrm{p}$. 
